\title{
THESIS
}

\section{ESTABLISHMENT AND CHARACTERIZATION OF DAY 30 EQUINE CHORIONIC GIRDLE AND ALLANTOCHORION CELL LINES}

\author{
Submitted by \\ Saleh M. Salman \\ Department of Animal Sciences
}

In partial fulfillment of requirements
for the Degree of Master of Sciences

Colorado State University

Fort Collins, Colorado

Spring 2019

Master's Committee:

Advisor: Jason E. Bruemmer

Co-Advisor: Gerrit Bouma

Christianne Magee

Pablo Pinedo

Quinton Winger 
Copyright by Saleh M. Salman 2019

All Rights Reserved 


\section{ABSTRACT \\ ESTABLISHMENT AND CHARACTERIZATION OF DAY 30 EQUINE CHORIONIC GIRDLE AND ALLANTOCHORION CELL LINES}

Establishing cell lines is a good model for experimental applications to study molecular mechanisms and cell-specific gene expression. A human resistant telomerase reverse transcriptase (hTERT) lentivirus was utilized to establish stable equine embryonic cell lines. Equids have a diffuse epitheliochorial placenta, where the invasive trophoblast is represented by the chorionic girdle (CG) and the noninvasive trophoblast are the allantochorion (AC). Embryonic CG cells are unique to horses compared to other farm animals' embryos. The CG cells are the predecessor of endometrial cups (EC) that differentiate, proliferate, and invade the endometrium by day 38 of pregnancy, yet morphologically, both have similar characteristics supporting the fetal origin for EC. The CG cells have a crucial role in equine chorionic gonadotropin (eCG) production and maintenance of pregnancy during the first trimester. This study has three objectives: 1) establishing a stable cell line from day $30 \mathrm{CG}$ cells and AC using lentivirus encoding $h T E R T ; 2$ ) Characterization of day $30 \mathrm{CG}$ cells and AC cell morphology and expression of eCG alpha $(e C G \alpha)$ and beta $(e C G \beta)$ subunits, major histocompatibility complex class II (MHC II), and Kisspeptin receptor (KISSIR) in CG and AC cells; 3 ) investigating eCG protein production in vitro from day 30 CG and AC cells. Reverse transcriptase (RT) PCR was used to study gene expression in cells and radioimmunoassay (RIA) was used to investigate protein presence in the media. We established a hygromycin-resistant day $30 \mathrm{CG}$ and $\mathrm{AC}$ cell lines that express $e C G \alpha, e C G \beta$, and hTERT and confirmed using RT-PCR yielding the predicted bands. The cell lines were maintained 
for 16 passages, 10 of which were cultured after the lentiviral infection steps. Also, we characterized CG cells as fast-growing, large, binucleated, and epithelioid, and AC cells as rapidgrowing showing smaller, squamous, mononucleate, epithelioid, and elongated fibroblastic cells. The RT-PCR results showed $e C G \alpha$ and $e C G \beta$ subunits are expressed by both day $30 \mathrm{CG}$ and AC cells, but MHC II and KISSIR genes were not expressed in either of cells. Moreover, RIA results showed that day $30 \mathrm{CG}$ cells did produce eCG protein in vitro earlier than what previous literature has shown. However, day $30 \mathrm{AC}$ cells did not produce eCG protein in vitro, and both CG and AC cell lines stopped secreting eCG in the media after the lentiviral infection. 


\section{ACKNOWLEDGMENTS}

The famous Nelson Mandela said, "Education is the most powerful weapon which you can use to change the world." All great civilizations in human history were built based on science and education--from the great Ancient Egyptians, Ancient Greece, Roman Empire, Islamic Civilization, to our current global civilization led by the United States of America. History has shown time and time again how powerful education in changing the fate of human's life and civilization. However, the pursuit of science and education -especially higher education and graduate school- is never an easy feat. "The pursuit of science is demanding, if you give your all, it won't give you but some of its wisdom." Arabian proverb. Thus, I am here acknowledging the most influencing people in my life, who bared with me in my pursuit of education and academia.

To the Binational Fulbright Commission in Egypt, thank you for choosing me among thousands of applicants to study my Master's degree and represent Egyptians here in the great US universities. Your huge investment in my education and career will not be forgotten, and I will do my best for the rest of my life to spread my positive experience and acquired knowledge of around the world.

To my sister, Doaa and my brother-in-law, Motamed, thank you for attracting me towards Animal Sciences and veterinary. Both of you are the reason for choosing the College of Agriculture and Animal Science as my major. Your continuous educational support is what later got me hired by Assiut University for a tenure position as a TA/RA.

To my committee; Drs. Bruemmer, Bouma, Magee, Pinedo, and Winger for being great educators and supportive mentors. To my co-advisor Dr. Bouma, who is the most enthusiastic teacher I have ever seen in my life, thank you. Also, thank you for opening up your ARBL 
laboratory, providing me with all the academic pieces of advice, and answering my never-ending questions. And to Dr. Winger, who is one of the most knowledgeable professors on early embryonic development and fertilization, thank you. You added a great value with your biomedical science perspective to my research. To Dr. Pinedo, who instructed one of my best courses on bovine reproduction and gave me a hands-on experience on bovine artificial insemination, thank you. Your international experience and perspective helped me better understand the US universities system and made me a better graduate student. To Dr. Magee, who taught me equine artificial insemination, heat check, and early pregnancy ultrasonography, thank you. The summer of 2018 was the most educative and fulfilling time in my life. Your energy for research and love for academia is inspiring, and your kind, friendly, and patient way of teaching is unparalleled.

To my advisor Dr. Bruemmer, who took a chance on an international student who had no experience in equine science, thank you. I will never forget what you said when I approached you to become my advisor. You said, "You are more than qualified to join our lab." Thank you for being the best academic advisor I ever had in my life. Your amicable nature and easy-going style provided the best environment to study, teach, and research equine reproduction.

Finally, to my parents; my mom, Nadia and my dad, Mahmoud, thank you very much for raising me on the love of science and respect for education. Because both you are teachers, our conversations were always constructive to deliver a point and educate me on the world that I will grow up in. You raised me to have a strong character, a leader who speaks up and don't fear public speaking. You also pushed me towards academic excellence and exposed me the great encyclopedia books, quizzed me on famous scientists, and bought me sci-fi books. Your rewarding me for reading books and obtaining excellent grades built up my passion for science and academia. From the bottom of my heart, thank you for everything. 


\section{TABLE OF CONTENTS}

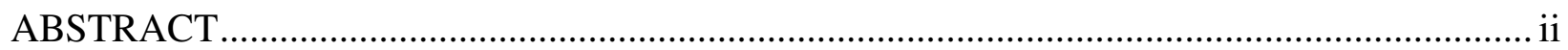

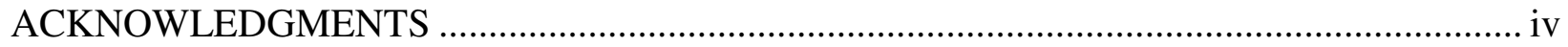

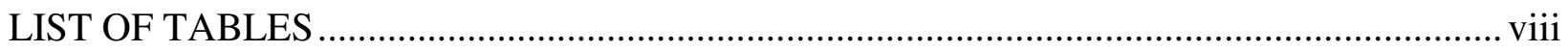

LIST OF FIGURES ..................................................................................................

CHAPTER I: INTRODUCTION (REVIEW OF LITERATURE)............................................ 1

Equine reproduction ....................................................................................................... 1

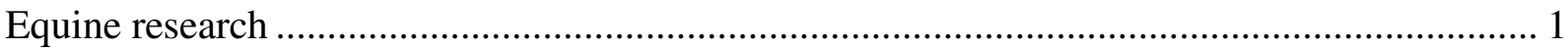

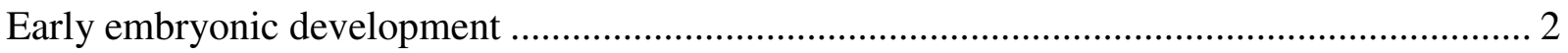

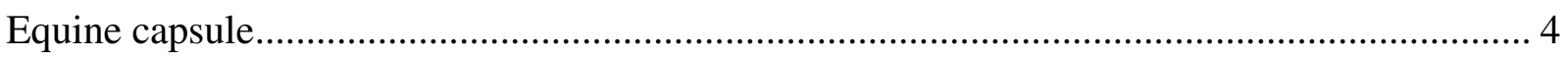

Day 30 embryo and chorionic girdle ................................................................................. 4

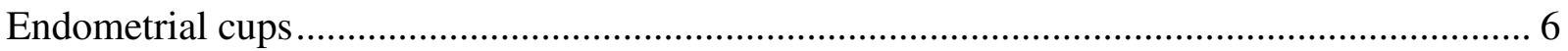

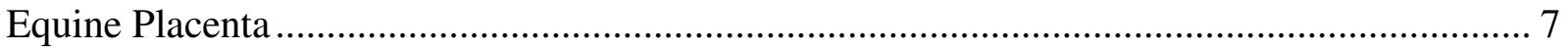

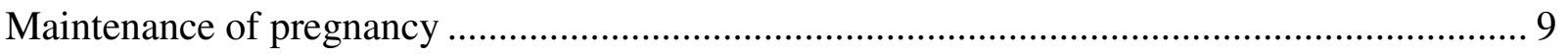

eCG

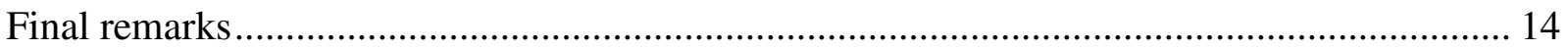

CHAPTER II: ESTABLISHMENT AND CHARACTERIZATION OF DAY 30 EQUINE CHORIONIC GIRDLE AND ALLANTOCHORION CELL LINES ........................................ 16

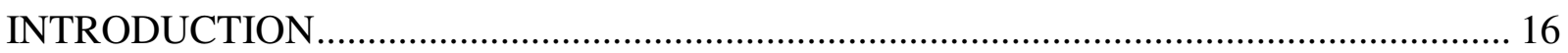

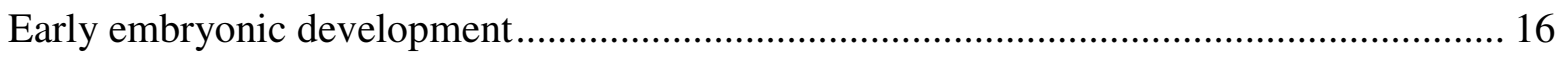

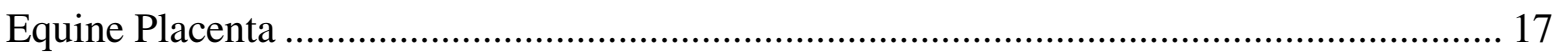

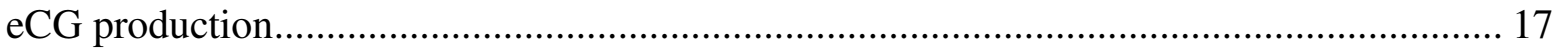

Expression of MHC II and KISS1R in day 30 embryo ................................................... 20

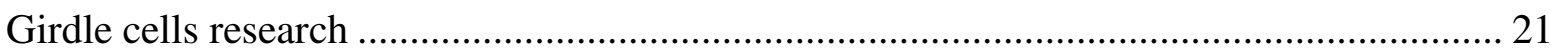

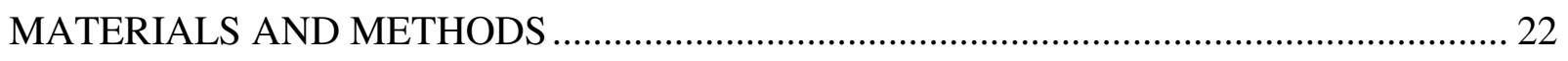

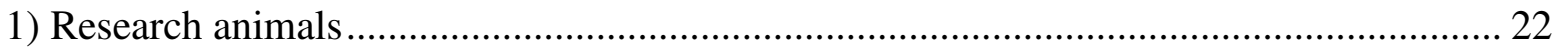

2) Collection and isolation of chorionic girdle and allantochorion cells.............................. 22

3) Chorionic girdle and allantochorion cells culture …………........................................... 23

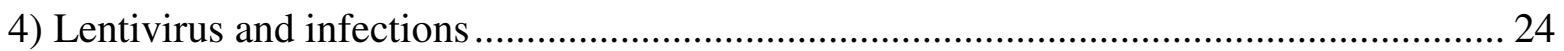

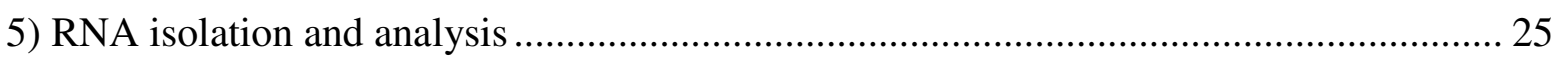

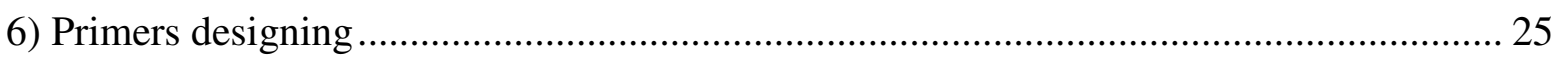




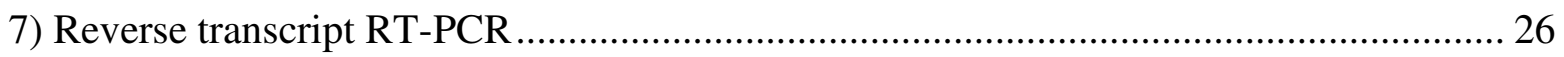

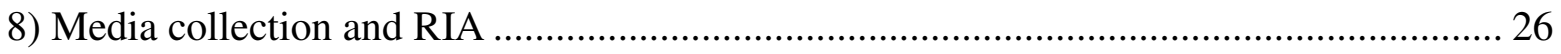

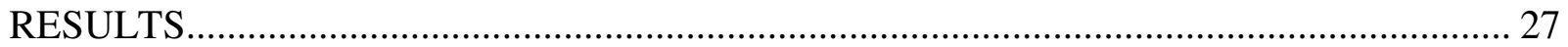

1) Establishment of chorionic girdle and allantochorion cell lines ........................................ 27

2) Characterization of day 30 embryo's chorionic girdle and allantochorion ....................... 27

3) $\mathrm{eCG}$ protein production in vitro from day 30 trophoblast cells ....................................... 28

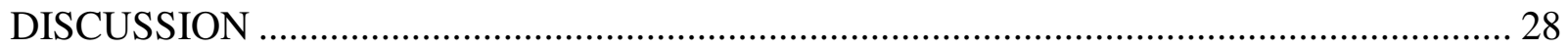

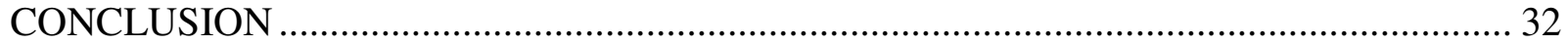

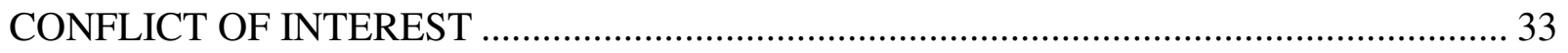

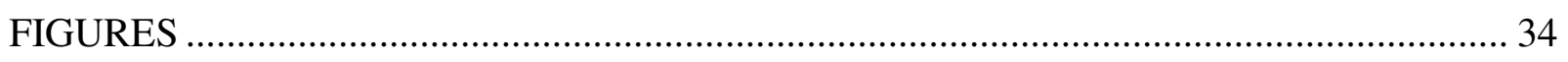

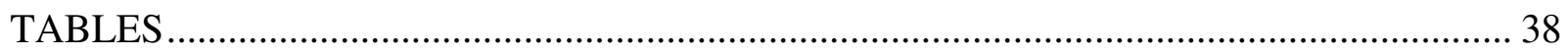

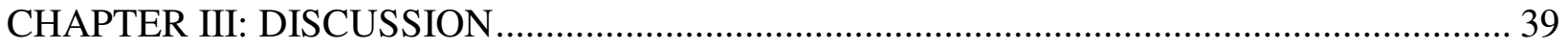

eCG mechanism to improve reproduction ......................................................................... 40

Girdle cells current and future research ..................................................................................... 40

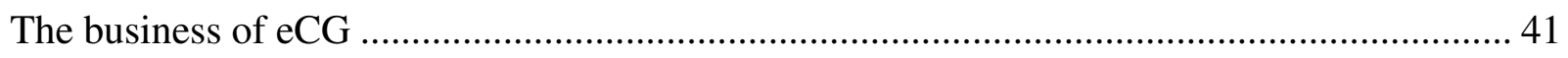

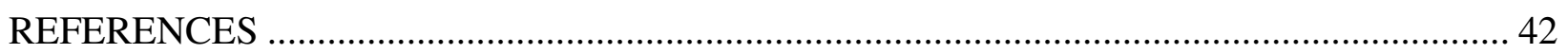




\section{LIST OF TABLES}

TABLE 1: Reverse transcripts-PCR primers sequences............................... 38 


\section{LIST OF FIGURES}

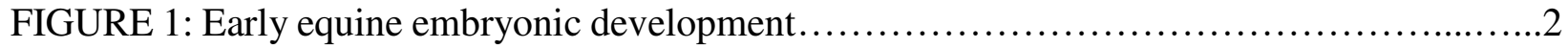

FIGURE 2: Equine embryo mobility................................................ 3

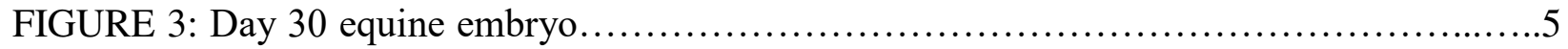

FIGURE 4: Characterization of Day 30 CG cells..............................................6

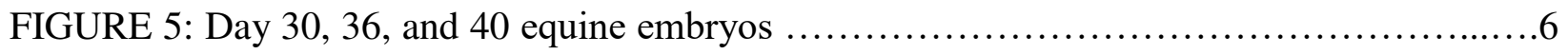

FIGURE 6: Equine diffuse placenta ........................................................ 9

FIGURE 7: Maintenance of pregnancy hormones..................................... 10

FIGURE 8: A linear structure of mammalian gonadotropins................................ 12

FIGURE 9: Reverse transcripts-PCR for chorionic girdle passages..............................34

FIGURE 10: Reverse transcripts-PCR for allantochorion passages girdle............................34

FIGURE 11: Reverse transcripts-PCR for CG cell line..................................................34

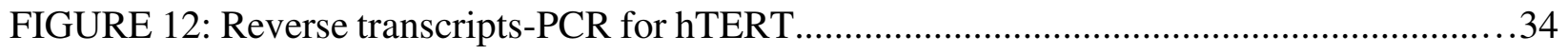

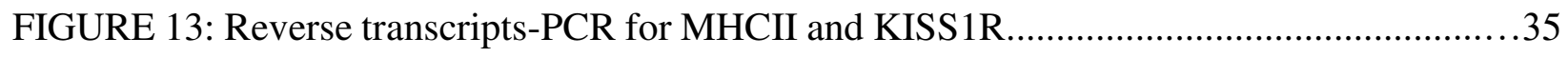

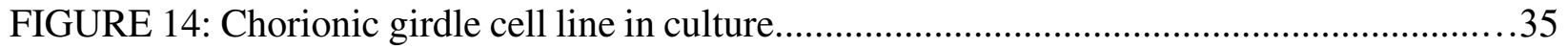

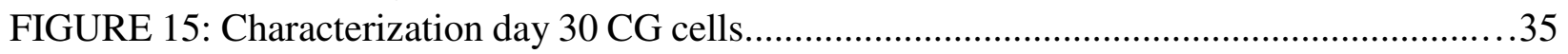

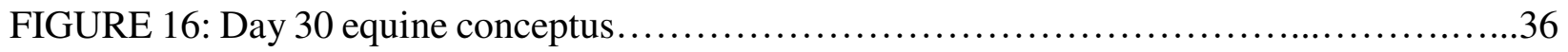

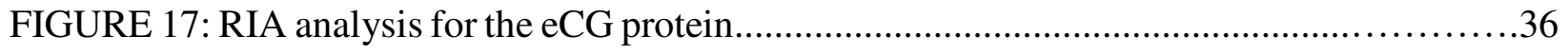

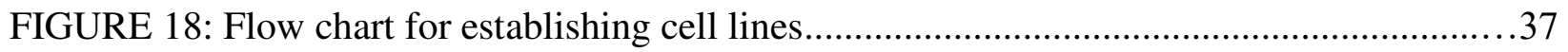




\section{CHAPTER I: INTRODUCTION (REVIEW OF LITERATURE)}

\section{Equine reproduction}

Equids are seasonally polyestrous species and photoperiod-driven breeders that become reproductively active during long daylight season. The duration of mare's pregnancy varies from 330 up to 350 days. Mares have a 21-day estrous cycle that is separated by 4 periods; proestrus, estrus, metestrus, and diestrus that can be divided into two separate ovarian phases. The follicular phase spans for approximately 7 days and ends 24-36 hours after ovulation. It has been

shown that the best time to breed the mare is 12 hours before ovulation which results in high conception rates (Woods et al., 1990). The luteal phase, which spans for about 14-15 days, is when progesterone (P4) is produced from the corpus luteum (CL). Production of P4 protects the embryo so the mare does not have a failed pregnancy in early days of embryonic development.

\section{Equine research}

Early equine embryonic development is a quite fascinating research venue, yet it is one of the most challenging compared to the reproduction of other farm animals. These challenges stem from the fact that horses are unique in many aspects. Horses' early embryos are exceptional. The only species that has a mobile embryo for the first 15 days of development are equids (Ginther, 1983).

Thus, a major research venue is equine maternal recognition of pregnancy (MRP) (Short, 1969), which is still not fully understood. Equine MPR mechanisms are not controlled by one major factor like human chorionic gonadotropin (hCG) in human or interferon tau in ovine and bovine species (McDowell et al., 1988). Studies have shown that MRP is controlled by multiple factors including the physical interaction between the embryo and endometrium along with embryonic secretion and signals (McDowell et al., 1988). Also, compared to other farm animals, the equine embryo stays 
spherical and does not elongate and attach to the endometrium until day 38 of pregnancy by forming endometrial cups (Allen \& Moor, 1973). Besides rabbits, the only other farm animal that has a capsule that encloses the embryo until day 21 of pregnancy is horses. The equine capsule develops between the trophoblast and zona pellucida a day after the blastocyst reaches the uterine body. The capsule existence led to the limitation of using in vitro fertilization (IVF) and in vitro maturation (IVM) (Galli et al., 2004). Moreover; the only species besides primates that produces embryonic chorionic gonadotropin are equids. The production of equine chorionic gonadotropin (eCG) is critical to understand maintenance of pregnancy and why the mare does not reject that spherical, and yet to be attached embryo (Min et al., 1996). In summary, I am investigating day 30 embryo to characterizes the chorionic girdle and allantochorion cells, establish stable cell lines from day 30 chorionic gridle and allantochorion cells, and determine whether eCG is produced in vitro by day 30 in pursuit of better understanding of equine maintenance of pregnancy.

\section{Early embryonic development}

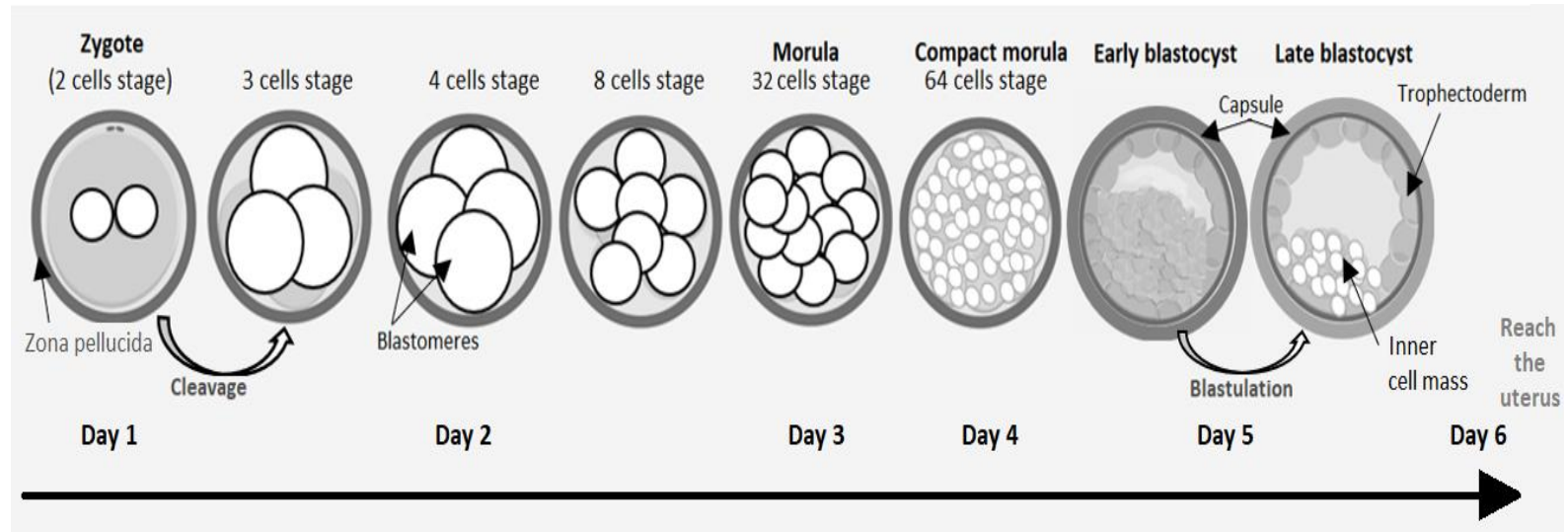

Figure 1: Early equine embryonic development. Day 0-6 development that shows the earliest stages of equine embryo. This figure is modified from (K. J. Betteridge, 2007).

After fertilization, the cells within embryo goes through a series of multiplication from zygote to four-cells, morula by day 3, and then reaches the blastocyst stage by day 6 (Vanderwall, 1996) 
when it enters the uterine horn (Freeman et al., 1991). The inner cell mass of the blastocyst is amassed at one pole, which will develop into the embryonic disc, then into the embryo proper, and eventually to the foal (Vanderwall, 1996). The blastocyst outer layer of cells are ectodermal cells -known as the trophoblast- will develop the placenta during the pregnancy (figure 1).

\section{Embryo mobility}

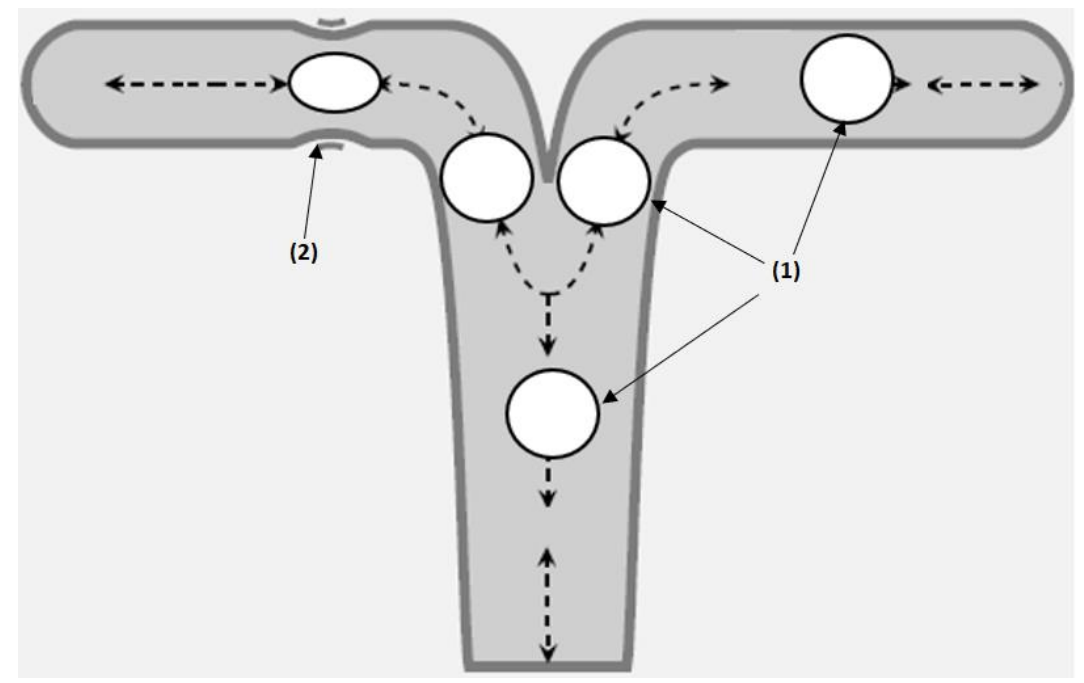

Figure 2: Equine embryo mobility. (1) Day 11-15 embryo. (2) Embryo produces a myometrial stimulant that stimulates uterine contractions causing embryo mobility. This figure is modified from (Ginther, 1998).

Equine early embryonic development and placentation are unique in comparison to other farm animals and other mammals. Studies have shown that the embryo reaches the uterus at day 6 (Freeman et al., 1991) and stays mobile until day 15 post conception. During the mobility period, the embryo physically contacts with $80 \%$ of the uterine lumen (Ginther, 1998; Leith \& Ginther, 1984). Embryo is thought to produce a myometrial stimulant that stimulates uterine contractions causing embryo mobility (Ginther, 1998). Embryo mobility stops abruptly when the uterine tonicity increases on day 17 and lead to embryo fixation at the base of one of the uterine horns (Ginther, 1998). Research in equine MRP suggests that the physical interaction between the 
embryo and the endometrium is critical in recognition of pregnancy (McDowell et al., 1988). In most farm animal species, when the embryo reaches the uterus, it starts elongating and invades the endometrium, but in equids, it stays spherical developing a relatively non-invasive placenta compared to human and rodents. By day 21, the embryo is settled at the base of one of the uterine horns, but it does not attach to endometrium by forming the endometrial cups until around day 38 (Allen \& Moor, 1972) (figure 2).

\section{Equine capsule}

On day 21 , multiple ultrasound studies have shown that the embryo is fixed at one of the uterine horns and remains spherical due to the acellular capsule that maintains the embryo physical structure (Betteridge, 1989). Another critical function to the capsule is that it prevents the embryo from early attachment to the endometrium (Stout et al., 2005), since embryo mobility is crucial to equine MPR. It was believed that endometrial glands produce an exocrine secretion that the capsule the accumulates and later releases as the antiluteolytic signal (Amoroso, 1952) for MPR, yet it was never proven. The capsule dissolution (disappearance) approximately by day 21 (Enders \& Liu, 1991).

\section{Day 30 embryo and chorionic girdle}

By then, the yolk-sac covers half of the embryo and the three-layered wall has developed a layer of the mesoderm. Blood capillaries have started developing in the mesoderm near the embryo proper (Ginther, 1998). By day 30, the size of the allantoic sac is increased and the embryo proper is moved toward the endometrium, and the yolk-sac is decreased in size (Ginther, 1998). From day 28 until day 40, the allantoic sac is progressively increasing, and the yolk sac is progressively decreasing in size. At the junction of the two sacs, the chorionic girdle emerges as early as day 28 (Ginther, 1998). 


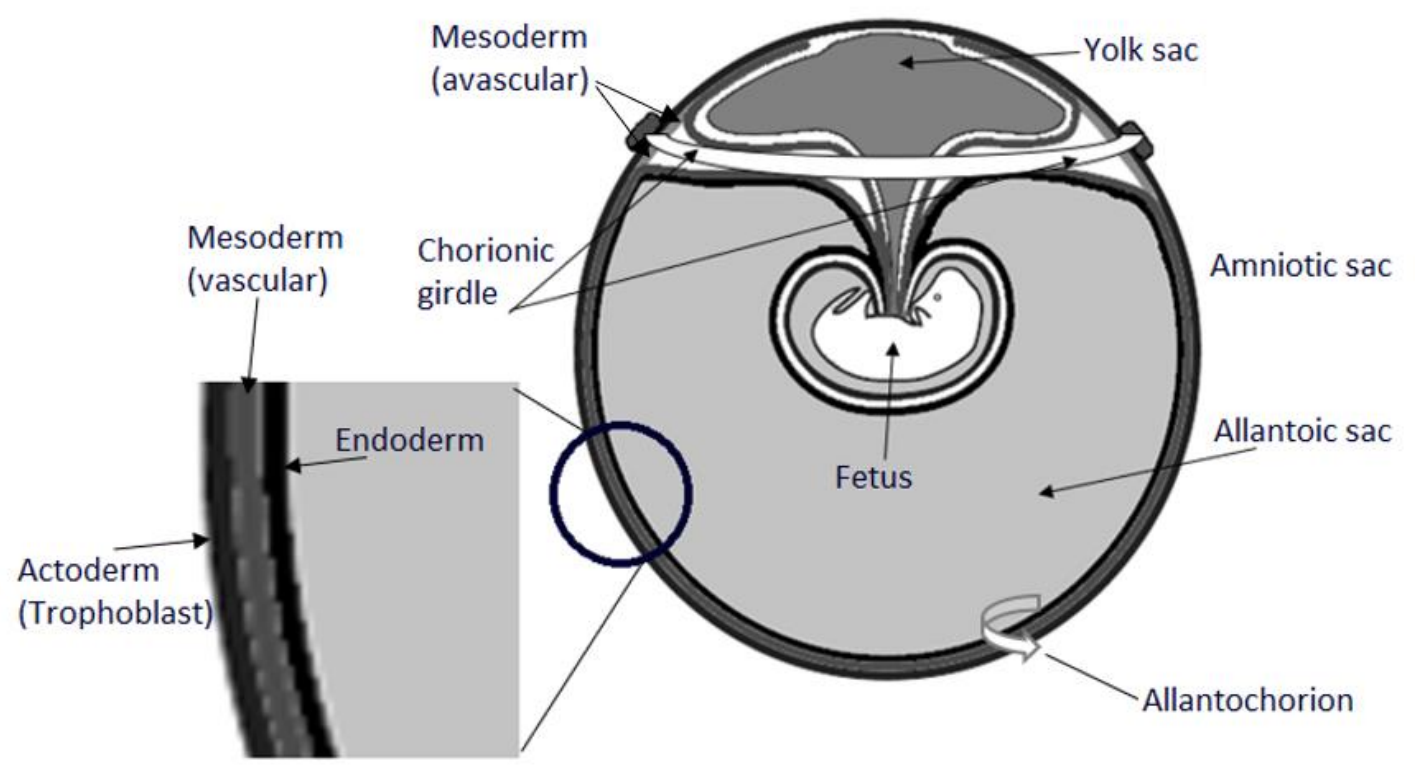

Figure 3: Day 30 equine embryo. This cartoon illustration of day 30 equine embryo is modified from (Ginther, 1998).

The chorionic girdle (CG) is the specialized invasive trophoblast and the allantochrion (AC) is the non-invasive trophoblast of the equine embryo (figure 3). These CG cells were characterized as fast-growing in culture media in vitro and displaying large, binucleated, well-defined, epithelioid, and decidual-like cells similar to endometrial cups morphology (Allen \& Moor, 1972). The AC cells have a faster cell growth rate in vitro relative to the girdle cells and they are displaying smaller -relative to girdle-, squamous, mononucleate, epithelioid, and elongated fibroblastic cells (Allen \& Moor, 1972) (figure 4). The girdle is a white band that encircles the embryo horizontally until day 38 when the girdle cells invade the endometrium to form the endometrial cups (Ginther, 1998). The allantochorion is the three layered embryonic skin that engulfs half of the embryo at day 30 of conception (Ginther, 1998). 


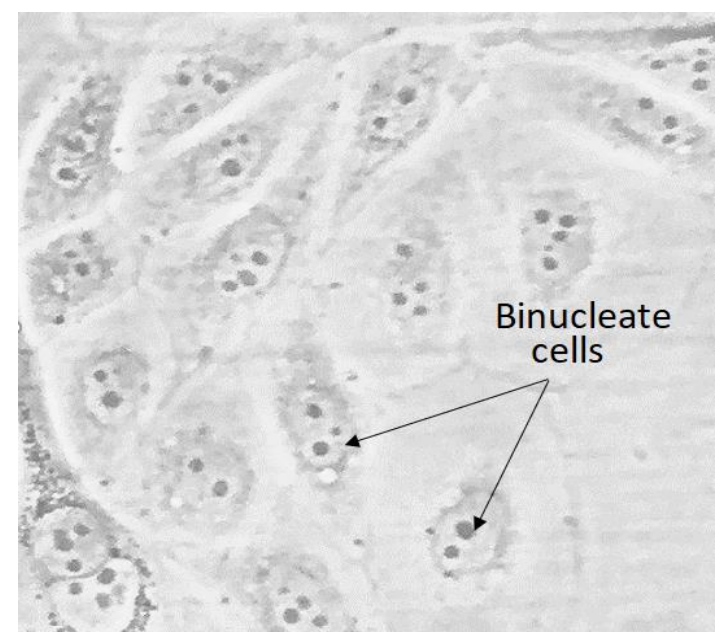

Figure 4: Characterization of day 30 CG cells. The girdle cells are large, epithelioid, binucleate cell (40X scale). (Salman et al., 2019- Unpublished).

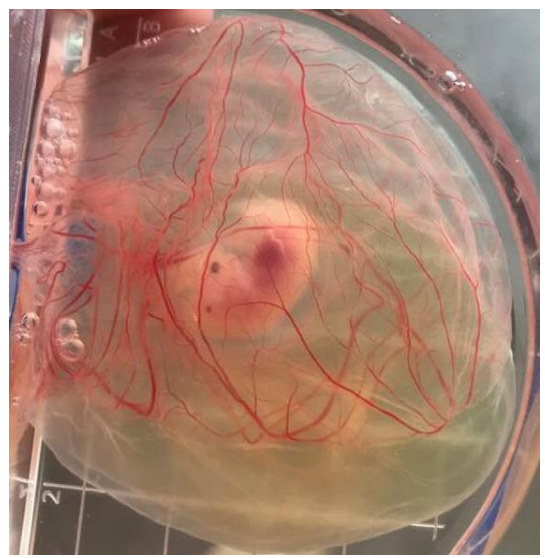

Day 30 equine embryo

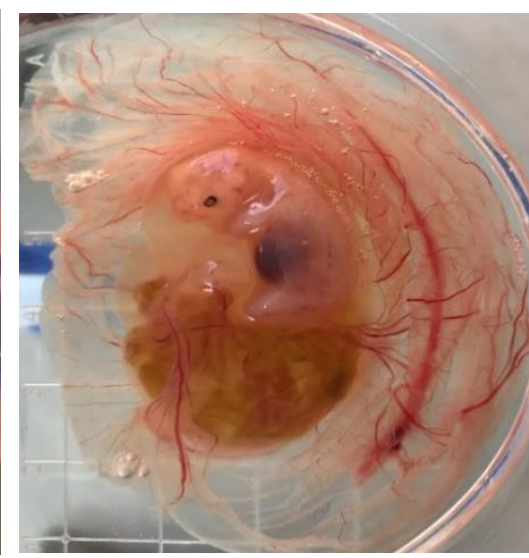

Day 36 equine embryo

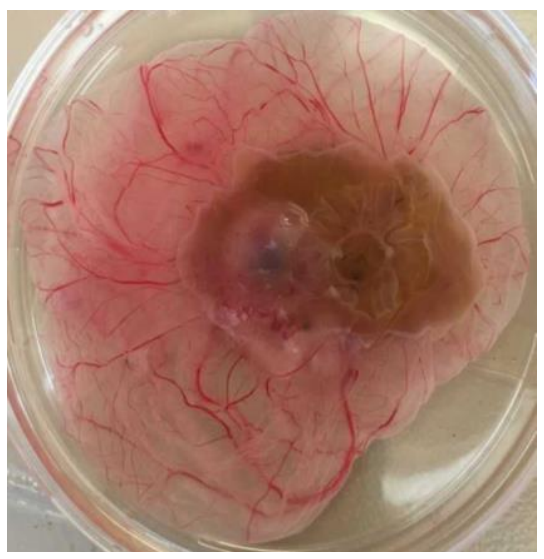

Day 40 equine embryo

Figure 5: Days 30, 36, and 40 equine embryos. Pictures are courtesy from Dr. Christianne Magee, Colorado State University, CO, 80523.

\section{Endometrial cups}

The endometrial cups are a unique placental structure for the equid species. Formation of such structure takes place around day 38-40 from conception (Allen et al., 1973). Endometrial cups involve intertwined placental and maternal cells representing a convoluted system between the conceptus and the uterus (Samuel et al., 1975). Studies have shown that the chorionic girdle develops between days 28-35 and reaches maturity by day 36 is a 9-mm wide honey-colored 
(figure 5) band that only a small portion invades the endometrial epithelium and finally attach the embryo the uterus (Allen et al., 1973). Both girdle cells (the forerunners of endometrial cups) and the endometrial cups produce equine chorionic gonadotropin (eCG) in vivo and in vitro starting from day 35 (Allen et al., 1973). The cups have an irregular shape that forms longitudinal rings along the endometrial wall, and each cup represents a distinct collection of adjacent cells with either a maternal or fetal genotype (Allen, 1982). Because the fetal antigens are foreign to the mare, an influx of immune lymphocytes takes place as a pregnancy cell-mediated immune response (Allen, 1982). Thus, studying such unique immunological features of the endometrial cups would be very interesting.

\section{Equine Placenta}

Research in the early 70's described the early embryonic development in mice as a model for mammalian embryo (Hillman et al., 1972). They discovered that the blastocyst has two types of cells. First, ectodermal (trophectoderm) cells which also called the trophoblast cells, gives rise to only the placental tissues. These trophoblast cells continue to develop as the placenta and make contact with the endometrium throughout pregnancy (Hillman et al., 1972). Second, the inner cell mass (ICM) which give rise to everything in the mammalian body but the placenta (Hillman et al., 1972). Even as early as day 7, the ICM cells can be distinctly differentiated, and each of them will develop to certain systems and organs (Balakier et al., 1982). Equids have a diffuse epitheliochorial placenta, in which the invasive trophoblast is represented as the chorionic girdle (CG) and the noninvasive trophoblast are the allantoic trophoblast (Gerstenberg, et al., 1999). Around day 21, the capsule disappears (dissolute) (Enders \& Liu, 1991) and thus, exposes the trophoblast to the external environment allowing the trophoblast cells to continue its development. The mare's placenta develops these unique chorionic girdle cells are between day 25 and 32 and 
establish this unique structure (Allen et al., 1973). By day 35, the trophoblast cells are differentiated to two types of cells. First, fully differentiated binucleated minor invasive chorionic girdle cells and second, a major non-invasive allantochorion cells (Hamilton et al., 1973). At day 35, the conceptus is still spherical and the invasive trophoblast cells are thick, annulate (having rings), and prominent (Hamilton et al., 1973). In fact, the invasive trophoblast of the girdle cells turns to honey-like instead of white transparent color at day 30 (Rowlands, 1963). These invading cells of the chorionic girdle pack together in the endometrial stroma to give rise to the endometrial cups (Allen, 1975). Research has shown the fetal cup cells elicit a maternal immune response that results in accumulation of leucocytes around each cup (Allen, 1982). Thus, they stimulate a strong maternal humoral and cell-mediated immune responses which reduce their lifespan significantly accelerating their demise and removal from endometrium by day 120 (Samuel et al., 1975) (Allen, 1982). Around day 40, the second type of trophoblast, the non-invasive trophoblast, also known as allantochorion, establish a steady, stable, and strong microvillous that contact with the endometrium. The true placentation takes place when the allantochorion non-invasive cells fully interdigitate with the endometrium (Samuel et al., 1975). Thus, forming the proper villous contact between the fetal and maternal counterparts (Samuel et al., 1975). By day 60, the non-invasive allantochorion cells form pronounced finger-like villi which diverge into multiple branches which gives rise to the microcotyledonary structure and the mature equine placenta (Samuel et al., 1974). The contact happens at the epithelium level and for the next 100 days, it establishes a highly complex, multibranched, and integrates with the endometrium. This placenta forms a microcotyledonary haemotrophic exchange points that canvas the entire surface of the diffuse epitheliochorial placenta (Samuel et al., 1974). 


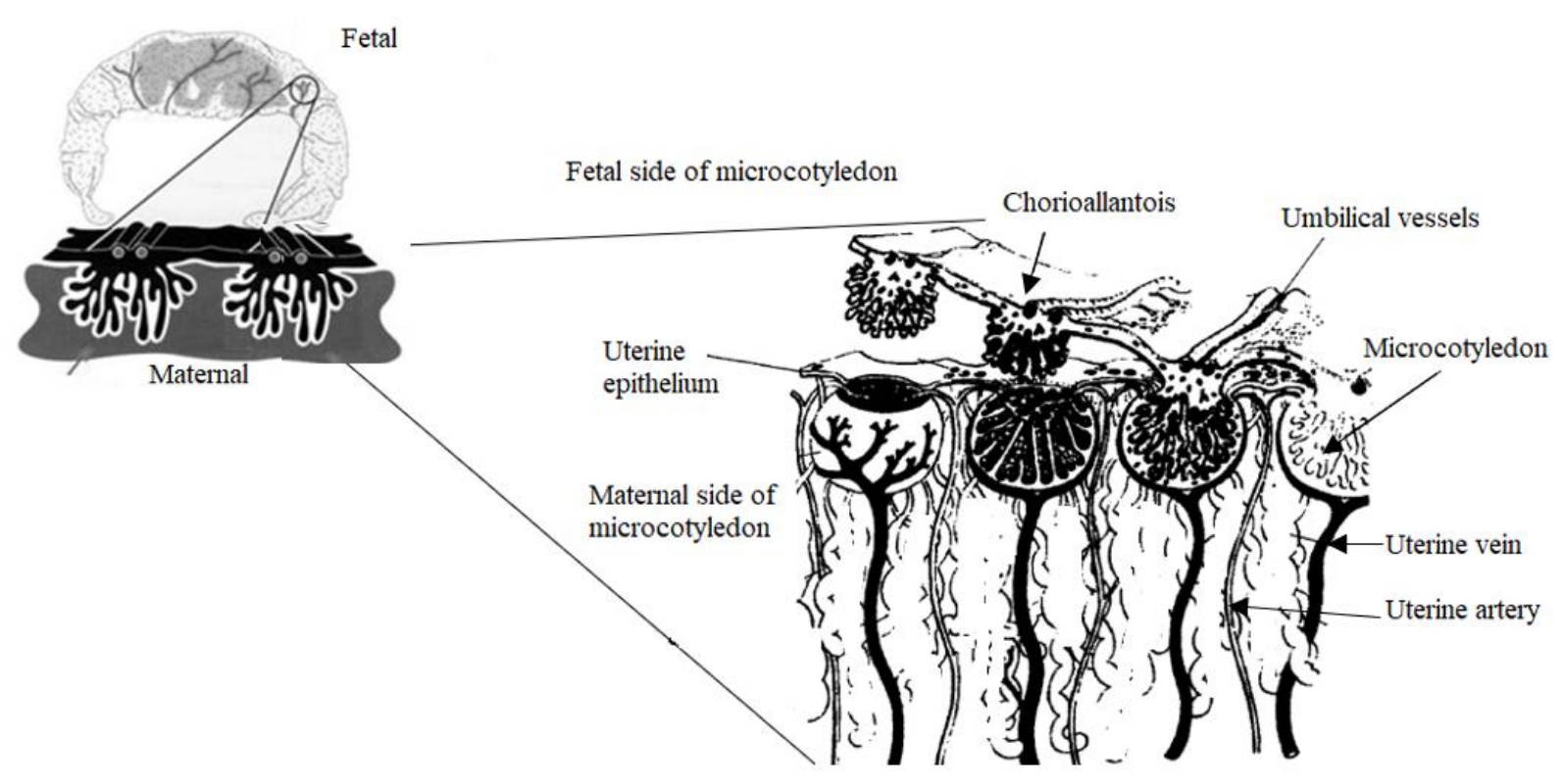

Figure 6: Equine diffuse placenta. Placenta showing the microcotyledon from both the fetal side and maternal side. This figure is modified from (Samuel et al., 1975).

\section{Maintenance of pregnancy}

Progesterone (P4) is a very important hormone in mare reproduction and all other mammals. In mares, when P4 its concentrations exceed the $4.0 \mathrm{ng} / \mathrm{ml}$ in blood mark, it prevents the mare from returning back to heat and thus it is critical to the maintenance of pregnancy. Because P4 production from the CL is vital to embryo development during the pregnancy, the presence of that embryo triggers blocking of luteolysis by the uterus in the pregnant mares. The endometrial glands produce an exocrine secretion that the capsule the accumulates and later releases as the antiluteolytic signal for maternal recognition of pregnancy (Amoroso, 1952). From day 4 until day 6, the embryo is in the oviduct producing prostaglandinE2 ( $\left.\mathrm{PGE}_{2}\right)($ Weber et al., 1991) then moves to the uterus by day 6. During embryo mobility from day11 until day16, the endometrium response to embryo presence and reduces prostaglandin F2-alpha (PGF2 $\alpha)$ (McDowell et al., 1988) and this is yet to be fully understood. This uterine-induced luteolysis is a unique feature in horses compared to other farm animals that utilize a rather unilateral pathway. Thus, that eerie mobility of embryos 
can be explained by that the embryo must contact the majority of $(80 \%)$ the uterine lining to achieve maternal recognition of pregnancy (McDowell et al., 1988). Hence, the small, spherical, and mobile embryo is key to blocking uterine- induced luteolysis. This was demonstrated by multiple studies that showed when embryos are restricted to one part of the uterus, it results in complete or partial luteolysis (McDowell et al., 1988; Ginther, 1998). Thus, these studies have shown that the interaction between the endometrium and the conceptus, allows the later to produce a substance that acts as an anti-luteolysin (figure 7).

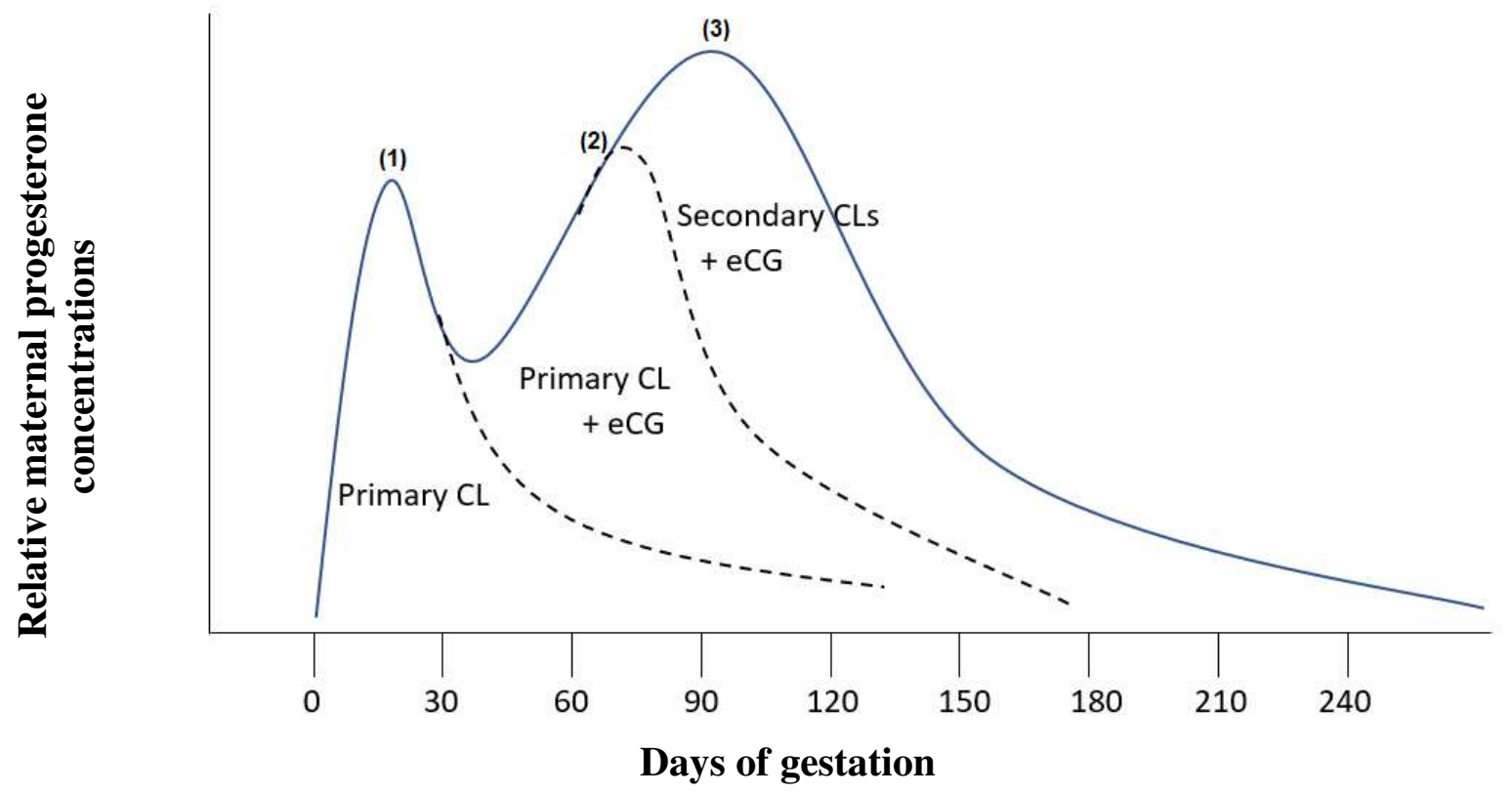

Figure 7: Maintenance of pregnancy hormones: (1) Progesterone (P4) from the primary CL increases rapidly after ovulation, and $\mathrm{P} 4$ will decreases (dashed line) by day 30 and the pregnancy would be terminated if not rescued. (2) When eCG triggers the primary CL, P4 production is stimulated and increased in the maternal blood. However, when eCG is not produced, P4 will continue decreasing (dashed line). (3) eCG continues to increase, secondary CLs develop and P4 increase until day 100. Day 100-until parturition, the placenta takes over P4 production. This figure is modified from (Murphy, 2012).

In pregnant mares, additional corpora lutea start forming around Day 40-45 of pregnancy. These secondary CL's are another unique feature to the mare and its reproduction. The aforementioned $\mathrm{CL}$ are stimulated by production of eCG from chorionic girdle and later endometrial cups. In turn, 
P4 levels start increasing progressively until they reach their peak in blood increase markedly due to the presence of secondary corpora lutea and reach peak levels at 70-90 days of pregnancy (Allen \& Moor, 1972), while the ovarian P4 declines steadily. By day 100 of gestation, the placenta fully takes over the production of P4 and progestagens which are unique for the mare (Bhavnani et al., 1969), and maintenance of pregnancy duties (Allen, 1975).

\section{$e C G$}

Equids have a diffuse placenta in which the invasive trophoblast is expressed as the chorionic girdle (CG) and the noninvasive trophoblast are the allantochrion (AC) (Allen \& Moor, 1972). Between day 25 and 32, the mare's embryo starts showing this unique chorionic girdle structure as the invasive trophoblast (Allen et al., 1973). Among mammals, the only two species known to synthesize a placental gonadotropin are primates and equids (Pierce \& Parsons, 1981). Equine chorionic gonadotropin (eCG) was first described almost 100 years ago by the German anatomist Wilhelm Schauder. Moreover, in 1943, Professor Harold Cole from the University of California at Davis and his team was first to recognize that eCG could be found in circulation during the first trimester of the pregnant mare (Cole \& Goss, 1943). The eCG is quite similar to human chorionic gonadotropin (hCG), in which it is found in the pregnant women's blood and urine, which led to the human pregnancy test by detecting for $\mathrm{hCG}$ in the urine. The eCG is a member of the glycoprotein hormone family. As a heterodimer, it is composed of two subunits, an alpha $(C G \alpha)$, and a beta $(C G \beta)$, both are encoded by a single copy gene in both primates and equids (Pierce \& Parsons, 1981). However, contrary to primates and hCG, the eCG $\beta$ and equine luteinizing hormone (eLH) are encoded by a single gene and also share a common proximal promoter region (Sherman et al., 1992). Both $e C G \alpha$ and $e C G \beta$ contain DNA regulatory elements that allow pituitary and placenta-specific expression (Talmadge et al., 1984a). 


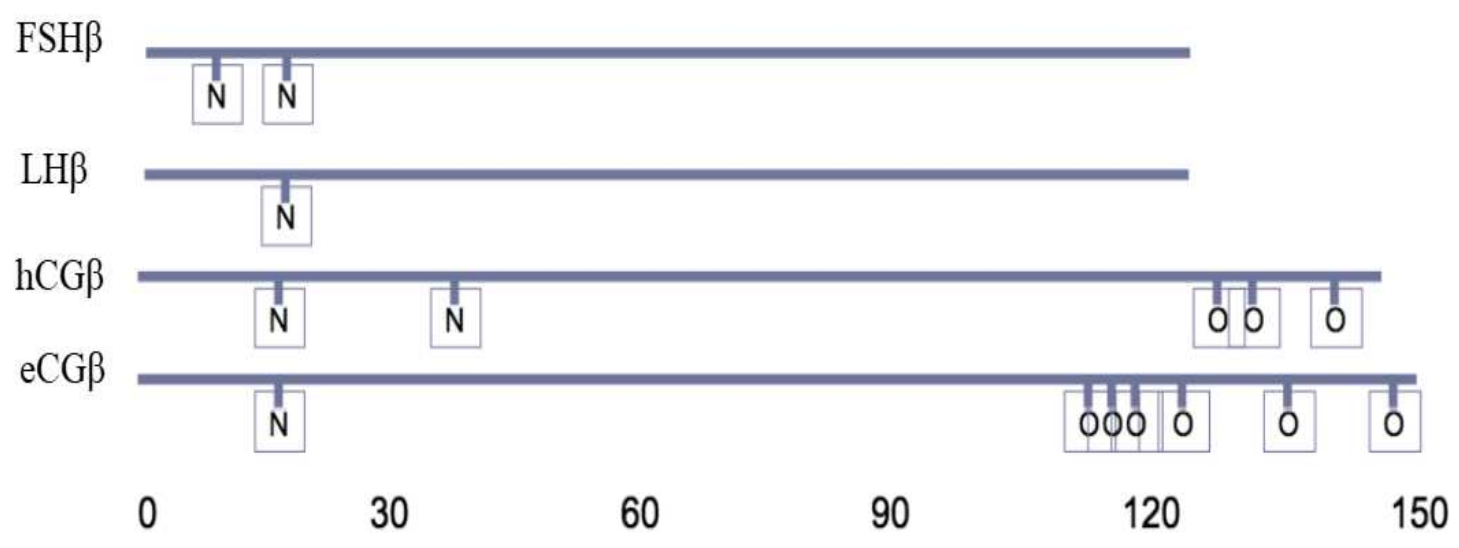

Figure 8: A linear structure of mammalian gonadotropins. Showing sites of attachment of carbohydrates. hCG and eCG have C-terminal extensions that are heavily glycosylated. This figure is modified from (Murphy, 2012).

Primates and equids are the only ones that express their $\alpha$ subunit genes in placenta, thus it can be surmised that horses are evolutionarily closer to humans than other farm animals (Fenstermaker $e t$ al., 1990). However, the placental expression of the CG $\alpha$ is quite different between primates and horses. The CG $\beta$ is highly homologous to the luteinizing hormone beta (LH $\beta)$ in primates. It is encoded by different genes but only as a single copy, and LH $\beta$ is only expressed in the anterior pituitary gland (Talmadge \& Fiddes, 1984b). In equids, a gene cluster is responsible for encoding $\mathrm{CG} \alpha$ which is only expressed in placenta. Moreover, $\mathrm{CG} \alpha$ and LH $\beta$ polypeptides are almost identical and encoded by the same gene, indicating the coordinated regulation between the pituitary and placenta in horses (Talmadge \& Fiddes, 1984b, Bousfield et al., 1987).

Studies have shown that eCG elicits response characteristics of both follicle stimulating hormone (FSH) and luteinizing hormone (LH) in the horse (Stewart et al., 1976). These, in turn, stimulate multiple follicles, leading to multiple CLs, and increasing P4 levels (Min et al., 1996). Thus, maintaining the pregnancy until the placenta completely takes over the hormones production by day 100 of conception. It has been established that the equine invasive trophoblast exhibit two 
distinct phases of development that end up as the histogenesis of endometrial cups (Allen \& Moor, 1972). The first phase takes place between days 25 and 32 post-conception when chorionic girdle emerges. The girdle cells white band is circumscribing the conceptus and can be identified at the junction between the regressing yolk sac and the enlarging allantochorion that is filled with capillaries (Samuel et al., 1975). The second phase begins by day 38 when girdle cells start invading the underlying stroma of endometrium then culminate, enlarge, and differentiate to eventually form the unique structure of the endometrium cups by day 50 (Antczak et al., 2013).

The eCG production in vivo starts as early as day 35 of conception and is secreted in the blood stream maintained for 80 days after that (Allen \& Moor, 1972). Also, when chorionic girdle cells are cultured they continue to produce eCG in the media for 180 days from culture (Allen \& Moor, 1972). Other studies confirmed that in vivo it reaches its peak production by day 70 of gestation (Murphy et al., 1991). This early production of eCG is critical to pregnancy maintenance because the conceptus is quite loose and poorly attached to the endometrium during that period. Even with the transplantation of chorionic girdle cells as a graft has demonstrated they have the same lifespan of equine endometrial cups in normal pregnancy. The grafted cells induced CL formation and progesterone production and maintenance as well, showing that ectopically transplanted equine trophoblast have an immunogenic role in a recipient (De Mestre et al., 2011). Finally, the demise of endometrial cups takes place and eCG production dwindles then shut down completely by day 100 (Allen \& Moor, 1972).

Because breeding in horses is seasonal during the summers, studying equine reproduction can be quite challenging. Also, horses are quite expensive to handle, and the economic aspects of their husbandry are challenging to equine research output. In addition to those challenges, the main 
factor that has hindered the progress of our scientific understanding of equine chorionic girdle is the unavailability of cell lines that produce eCG. In humans, choriocarcinoma (a malignant trophoblastic) cell lines that produce hCG gave researchers a great opportunity to deeply study the hCG production and placenta-specific gene expression (Nilson et al., 1991). It is paramount to maintain cell line authenticity during cell culture, meaning the chorionic girdle cell line should continue to express $e C G \alpha$ and $e C G \beta$ subunits, produce eCG in vitro in the media, and express the binucleate phenotype similar to endometrial cup cells (Thway et al., 2001).

Horses breed seasonally and rarely have more than a single conceptus per pregnancy in a given year, so primary cultures of girdle cells are vital to eCG, equine MRP, and maintenance of pregnancy research. However, without access to healthy pregnant mares to provide new conceptuses and subsequently girdle cells for culture every year the research will not take place. Thus, with such demand for frequent, available, and stable girdle cell line, establishing is chorionic girdle cell line is paramount. Also, the cell line could be a good solution to increase our understanding of early equine embryonic development and maintenance of pregnancy and avoid horse's reproduction limitations.

Thus, our study objectives are; first, to determine whether eCG is produced in vitro by day 30 chorionic girdle cells, second to characterize day 30 chorionic gridle gene expression, and third, to use hTERT hygromycin resistant retrovirus to immortalize these day 30 equine chorionic girdle cells that express both $e C G \alpha$ and $e C G \beta$ subunits.

\section{Final remarks}

This eCG cell line will provide a new model allowing for more investigation of $e C G \alpha$ and $e C G \beta$ subunits expression and reach a deeper understanding of their molecular mechanisms in the maintenance of pregnancy. Moreover; this cell line can be used in studying the immunological 
expression of the major histocompatibility complex (MHC) class I and, class II, and interleukin IL-22 genes (Mathias et al., 2010) that prevent mare from rejecting conceptus before the formation of the endometrial cups (Maher et al., 1996); (Donaldson et al., 1990); (Mathias et al., 2010). 


\section{CHAPTER II: ESTABLISHMENT AND CHARACTERIZATION OF DAY 30 EQUINE CHORIONIC GIRDLE AND ALLANTOCHORION CELL LINES}

\section{INTRODUCTION}

\section{Early embryonic development}

Equine early embryonic development and placentation are unique in comparison to other mammals. In most farm animal species, when the embryo reaches the uterus on day 6 (Freeman $e t$ al., 1991), it starts elongating and invades the endometrium, but in equids, it stays spherical, developing a relatively non-invasive placenta compared to other farm animals (Griffin et al., 1993). The equine embryo has another unique structure, the capsule. It is an acellular, thin, resilient, mucinous layer of glycoproteins that develops between the trophoblast and zona pellucida (Betteridge, 1989). One day after the embryo enters the uterus, the zona pellucida is shed and the capsule becomes the exterior layer of the embryo (K. Betteridge, 1989). Until day 15, the equid embryo is consistently moving and covering almost $80 \%$ of the uterus lumen (Ginther, 1985). Early interactions between the embryo and the endometrium are critical to maternal recognition of pregnancy (MRP) (Short, 1969), (McDowell et al., 1988), (Ginther, 1983). Along with physical interaction, there are multiple key factors that play a role in MRP, but they are still poorly understood (Leith \& Ginther, 1984). However, these factors signal the corpus lutetium (CL) to maintain progesterone $(\mathrm{P} 4)$ production to ensure pregnancy maintenance in the early days. The mechanism of such factors is still subject to many researches to better understand equine maternal recognition of pregnancy (McDowell et al., 1988). By day 21, the capsule disappears (Enders \& Liu, 1991), and the embryo is settled at the base of one of the uterine horns, but it does not attach to endometrium by forming the endometrial cups until around day 38 (Allen et al., 1973). The 
differentiated invasive girdle cells penetrate the luminal epithelium then invade deeper towards the endometrial stroma and attach the embryo to the endometrium for the first time before day 40 (Allen et al., 1973).

\section{Equine Placenta}

Equids have a diffuse epitheliochorial placenta in which the invasive trophoblast is represented as the chorionic girdle (CG) and the noninvasive trophoblast are the allantoic trophoblast (Gerstenberg, et al., 1999). Between day 25 and 32, the equine embryo develops a unique chorionic girdle structure (Allen et al., 1973). By day 35, the trophoblast cells are differentiated to two types of cells; 1) fully differentiated binucleated minor invasive chorionic girdle cells, and 2) major non-invasive allantochorion cells (Hamilton et al., 1973). These trophoblast cells form fetal cup cells that elicit a maternal immune response that results in accumulation of leucocytes around each cup accelerating their demise and removal from endometrium by day 120 (Allen, 1982). By day 40 , the true epitheliochorial placentation takes place when the allantochorion non-invasive cells fully interdigitate with the endometrium. Thus, forming the proper villous contact between the fetal and maternal counterparts. By day 60 , the non-invasive allantochorion cells form pronounced finger-like villi which diverge into multiple branches which gives rise to the microcotyledonary structure and the mature equine placenta (Samuel et al., 1974).

\section{eCG production}

Among mammals, the only two species known to synthesize a placental gonadotropin are primates and equids (Pierce \& Parsons, 1981). Equine chorionic gonadotropin (eCG) was first described over 100 years ago (Schauder, 1912). Moreover, in 1943, it was first recognized that eCG could be found in circulation during the first trimester of the pregnant mare (Cole, H. \& Goss, H.). It is quite similar to human chorionic gonadotropin (hCG), in which it is found in pregnant women's 
blood and urine. The eCG is a member of the glycoprotein hormone family. As a heterodimer, it is composed of two subunits, an alpha (CG $\alpha)$ and a beta $(\mathrm{CG} \beta)$, both are encoded by a single copy gene in both primates and equids (Pierce \& Parsons, 1981). Both $C G \alpha$ and $C G \beta$ contain DNA regulatory elements that allow pituitary and placenta-specific expression (Talmadge et al., 1984a). Compared to other species, primates and equids are the only ones that express their $\alpha$ subunit genes in placenta, thus it can be surmised that horses are evolutionarily closer to humans than other farm animals (Fenstermaker et al., 1990). However, the placental expression of the CG $\alpha$ is quite different between primates and horses. In primates, the CG $\alpha$ is highly homologous to the luteinizing hormone beta (LH $\beta$ ). It is encoded by different genes but only as a single copy, and LH $\beta$ is only expressed in the anterior pituitary gland (Talmadge \& Fiddes, 1984b). In equids, a gene cluster is responsible for encoding $\mathrm{CG} \alpha$ which is only expressed in placenta. Moreover, CG $\alpha$ and LH $\beta$ polypeptides are almost identical and encoded by the same gene, indicating the coordinated regulation between the pituitary and placenta in horses (Talmadge \& Fiddes, 1984b) (Bousfield et al., 1987). Also, it has been established that a single gene CG $\beta$ is evolved independently in primates and equids, thus using different mechanisms in their patterns of placenta-specific expression (Sherman et al., 1992).

Studies in vivo have shown that eCG production by the chorionic girdle cells starts as early as day 35 of conception, reaching its peak production by day 70 (Allan \& Moor, 1972; Murphy et al., 1991). Early production of eCG is critical to pregnancy maintenance because the conceptus is quite loose and poorly attached to the endometrium during that period. Even with the transplantation of chorionic girdle cells as a graft has demonstrated that they have the same lifespan of equine endometrial cups in normal pregnancy. The grafted cells induced CL formation and progesterone maintenance showing that ectopically transplanted equine trophoblast illicit an immune response, 
and will be eventually eliminated regardless of their location (De Mestre et al., 2011). Finally, the demise of endometrial cups takes place by a mechanism that needs more investigation, and eCG production dwindles then shut down completely by day 100 (Allen \& Moor, 1972).

Chorionic gonadotropins are secreted from endometrial cups to reach the maternal bloodstream acting as gonadotropin-like hormone to stimulate the development of secondary CL. The eCG elicits response characteristics of both follicles stimulating hormone (FSH) and luteinizing hormone (LH) in the horse (Min et al., 1996) (Saint-Dizier et al., 2004b). These, in turn, stimulate multiple follicles leading to multiple corpus lutea CLs and increasing of P4 levels (Min et al., 1996). Therefore, eCG ensures $\mathrm{P} 4$ levels in the blood stream during the first trimester of pregnancy, thus maintains the pregnancy until day 90-100 of conception (Bruce D Murphy \& Martinuk, 1991). The CLs persist until day 150 of gestation and are the main source of serum progestin concentrations during such period (Amoroso et al., 1948). After placentation, the placenta completely takes over maintenance of pregnancy, however, instead of $\mathrm{P} 4$, it produces progestin which is unique to equid species. Progestin reaches its peak by day 100 of conception and continues maintenance of pregnancy until parturition (Urwin \& Allen, 1982). Equine invasive trophoblast exhibit two distinct phases of development that result in the histogenesis of endometrial cups (Allen \& Moor, 1972). The first phase takes place between days 25 and 32 postconception when the of the chorionic girdle emerges. The white band of girdle cells circumscribes the conceptus and can be identified at the junction between the regressing yolk sac and enlarging allantochorion filled with capillaries. The second phase begins by day 38 when girdle cells start invading the underlying stroma of endometrium then culminate, enlarge, and differentiate to eventually form a unique structure of the endometrium cups by day 50 (Antczak et al., 2013). 


\section{Expression of MHC II and KISSIR in day 30 embryo}

Many studies have investigated the mechanism preventing the embryo rejection by maternal immune system. They demonstrated that down-regulation of specific genes know as major histocompatibility complex (MHC) is the primary mechanism to embryo preservation from maternal immunity (Antczak \& Allen, 1984). Many have studied how an embryo escapes maternal immune recognition while expressing both parental MHC class I and class II antigens (Billingham, \& Medawar, 1953). Other studies showed that if the trophoblast cells fail to express MHC molecules, the embryo will be prone to maternal immune attacks (Antczak \& Allen, 1984). Multiple studies showed that MHC I can be detected by day 32 of pregnancy, but not before (Maher et al., 1996)(Donaldson, et al., 1990). The maternal immune system is suppressed by altering the maternal immune cells from antagonizing the fetus to cooperating until the implantation (Baker $e t$ al., 2000). Also, MHC I antigens are detected by day 60 in the pregnant mare blood, but by day 45, it will be irreversibly lost from the endometrial cups surface after differentiation of girdle cells (Antczak et al., 1984). However, MHC class II is yet to be detected in mares non-invasive or invasive trophoblast before day 30 of gestation (Donaldson et al., 1990).

It is well-established that Kisspeptin has a critical role in regulating GnRH in most mammals (Skorupskaite etal., 2014). Kisspeptin (KISS1) is mainly expressed in the hypothalamus to regulate GnRH pulses in human and other mammals. Human placenta studies showed that Kisspeptin receptor KISS1R is also expressed in the placenta along with KISS1. These studies showed that KISS1R is expressed in cytotrophoblast trophoblast cells and have a critical role regulating trophoblast invasion in the body (Messager et al., 2005). 


\section{Girdle cells research}

Equids are seasonally polyestrous species and photoperiod-driven breeders that become reproductively active during long daylight season, which makes it challenging to study equine reproduction. Also, horses are quite expensive to handle, and the economic aspects of their husbandry are key for equine research output. Beside the seasonality of horse reproduction cycle and financials of its husbandry, the main factor that hindered the progress of our understanding of equine chronic girdle is the unavailability of cell lines that produce eCG. In humans, a choriocarcinoma cell line that produces hCG gave researchers a great opportunity to deeply study the hCG production and placenta-specific gene expressions (Nilson et al., 1991). The collection of the conceptus and its membranes by non-surgical lavage then isolated of chorionic girdle cells can be easily cultured and maintained for up to 6 months. During culture, eCG production continues by girdle cells while expressing a binucleate phenotype similar to endometrial cup cells (Thway et al., 2001). Because horses breed seasonally and rarely have more than a single conceptus per pregnancy in a given year, primary cultures of girdle cells could be vital to eCG research. However, without access to healthy pregnant mares to provide new girdle cells for culture every year, the demand for frequent, available, and stable girdle cell line becomes paramount. Also, understanding early equine embryonic development and its role in maintenance of pregnancy. Establishing chorionic girdle cell line is a great solution to study these research points and avoid horses' reproductive limitations. Thus, our study objectives were; first, study whether eCG is produced in vitro by day 30 chorionic girdle cells, and second, is to use of hTERT hygromycin resistant retrovirus to immortalize these day 30 equine chorionic girdle cells that express both $\mathrm{CG} \alpha$ and CG $\beta$ subunits. Hence, this will provide a new model allowing more investigation of eCG $\alpha$ and $\beta$ subunits expression and reach a deeper understanding of their molecular mechanisms in 
maintenance of equine pregnancy. Moreover; this cell line can be used in studying the immunological expression of the major histocompatibility complex (MHC) class I and, class II, and interleukin IL-22 genes (Mathias et al., 2010) that prevent mare from rejecting conceptus before the formation of the endometrial cups (Maher et al., 1996) (Donaldson et al., 1990) (Mathias et al., 2010).

\section{MATERIALS AND METHODS}

\section{1) Research animals}

Conceptuses were collected from three mares in June and July 2018 at facilities maintained and operated by Colorado State University in Fort Collins, CO, USA. Husbandry and experimental procedures were approved by the Colorado State University Animal Care and Use Committee (protocol 17-7169A).

Three mares were kept under ambient environmental conditions with free choice access to shelter, water, and hay. Palpation per rectum with ultrasonography was performed every 1-5 days as needed. Mares were bred via artificial insemination with 1 billion progressively motile spermatozoa from a stallion of known fertility from the CSU Equine Reproduction Laboratory. Mares were evaluated for ovulation once daily after insemination and were inseminated no more than twice, 48 hours apart. Ovulation was considered day zero, and mares were re-evaluated at days $12,16,25$, and 30 to confirm pregnancy before embryo collection (Dascanio \& McCue, 2014).

\section{2) Collection and isolation of chorionic girdle and allantochorion cells}

Three equine day 30 conceptuses were collected by non-surgical uterine lavage on day 30 of gestation (McDowell et al., 1990), (figures 14, 16). A Foley catheter that features a balloon cuff was used to administer lavage fluids trans-cervically into the uterine body. To assure the reflux of 
embryo and conceptus tissues through the cervix, the inflatable cuff was inflated. A 5-liters Hartmann's Solution lavage bag [Vetivex-Dechra, KS, USA] was used as the fluid lavage and administered through the catheter. Fluid flow was controlled by two clamps in a tubing system assisted the delivery of the conceptus from the base of the uterine horn and flushed out of the uterus through the catheter. In a sterile cup with a filter, all conceptus membranes and the embryo were collected. Under the dissecting microscope, the chorionic girdle was identified and dissected using iris scissors and fine forceps (McDowell, Sharp, Fazleabas, et al., 1988). The dissected sample was rinsed several times in Hank's balanced salt solution (HBSS) [HyClone Laboratories Inc. UT, USA] before dividing them to three samples: fixed; (5\% paraformaldehyde), snap-frozen; (samples contained in $1.7 \mathrm{ml}$ Eppendorf-tube plunged in liquid nitrogen), and culture, (suspended in HBSS until culturing).

\section{3) Chorionic girdle and allantochorion cells culture}

Samples were introduced to $15 \mathrm{ml}$ sterile collagenase solution (40 mg collagenase type 1 enzyme, $20 \mathrm{mg}$ bovine serum albumin (BSA) [Sigma-Alorich, WY, USA] in $40 \mathrm{~mL}$ of HBSS Solution and incubated for one hour at $37^{\circ} \mathrm{C}$ with shaking. Cells were then aspirated by small pipette and centrifuged at $500 \mathrm{~g}$ for 5 mins. Cells were resuspended in sterile culture Ham's F-12 media [Thermo Sciences, Inc., CO, USA]. Adding to the $500 \mathrm{ml}$ media; $50 \mathrm{ml}$ (10\%) fetal bovine serum (FBS) [Thermo Sciences, Inc., CO, USA], 5ml (1\%) insulin (5 mg/ml), transferrin (5 mg/ml), and selenium $(5 \mathrm{ng} / \mathrm{ml}), 5 \mathrm{ml}(1 \%)$ antibiotics: $(100 \mathrm{U} / \mathrm{ml})$ penicillin, $(0.1 \mathrm{mg} / \mathrm{ml})$ streptomycin, and $[0.25 \mathrm{mg} / \mathrm{ml}]$ amphotericin B. We used F-12 media without adding FBS for passage 6 of our experiment because of back-ordering issue. The single cell suspension was placed in $20 \mathrm{ml}$ media in T75 culture flasks [Celltreat, Inc., MA, USA] in $5 \% \mathrm{CO} 2$ at $37^{\circ} \mathrm{C}$. Cells were checked daily for growth and contamination and media was changed every three days or 72 hours. Cells were 
passaged to new flasks when they reach $75-80 \%$ confluence (Rose et al., 2016). For passaging the cells after reaching confluency, the cells were treated with $5 \mathrm{ml}$ trypsin $0.25 \%$ [Corning, Inc., NY, USA] incubated for 10 mins at $37^{\circ} \mathrm{C}$ in absence of media. The suspended cells were collected and frozen at $-80^{\circ} \mathrm{C}$ for later RNA and protein analysis.

\section{4) Lentivirus and infections}

A detailed protocol of lentivirus infection has been published previously (Hayer et al., 2016). Shortly, we utilized a lentiviral vector transfected into lenti-X 293T cells using a polyethyleneimine (PEI) transfection protocol to construct lentivirus is encoding pLV-hTERTIRES-hygro [Addgene, Inc., MA, USA] constructed by the Winger lab, Biomedical Sciences Department, Colorado State University, CO, USA, 80523. The 293T cells (not authenticated) were maintained in DMEM media (50 $\mathrm{ml} \mathrm{FBS,} 5 \mathrm{ml}$ ITS, and $5 \mathrm{ml}$ antibiotics/500 $\mathrm{ml}$ DMEM] until confluence. The transfected girdle cells were incubated with the virus for 24 hours then washed by PBS and resuspended in modified Ham's F-12 media for 3 days. After that, selection for hygromycin-B [Mirus Bio LLC., WI, USA] resistant cells were done using hygromycin-B media [100 $\mu \mathrm{g} / \mathrm{ml}]$ with no other antibiotics added to the media. A kill curve was performed in a 24-well plate to determine the dose of hygromycin-B needed for selection using doses of $0,25,50,100$, $200 \mu 1$ hygromycin/ml media. The 0,25 , and $50 \mu 1$ hygromycin doses killed only a small percentage of the cultured cells after 12 hours from culture and $100 \mu$ concentration killed approximately $80 \%$ of the cells, but the $200 \mu \mathrm{l}$ concentration killed $100 \%$ of cells. Thus, $100 \mu \mathrm{l}$ hygromycin/ml media (without added FBS) was the established concentration for hygromycin-B resistant cells selection. Following the manufacturer's protocol, the transfected cells were left in the same flasks for 7 days while changing the hygromycin media every 48 hours. This results in killing nearly $80 \%$ of the girdle cells and the rest were resistant to hygromycin and thus selected 
to be cultured. The cells were allowed to reach confluence and passaged 10 times. Seven samples were obtained and cryoprotected in liquid nitrogen and samples representing each passage were frozen into $-80^{\circ} \mathrm{C}$ for later analysis.

\section{5) RNA isolation and analysis}

Total RNA was isolated using Trizol Reagent [Life Technologies, Inc., Gaithersburg, MD, USA]. A $750 \mu 1$ Tri-reagent was added to $250 \mu \mathrm{l}$ of cell suspension in a $1.7 \mathrm{ml}$ Eppendorf-tube and mixed thoroughly. After storing at room temperature for 5 mins, $200 \mu 1$ of chloroform was added and the sample was vortexed then left for 10 mins until the aqueous phase was clear. Samples were centrifuged $10000 \mathrm{~g}$ for $10 \mathrm{mins}$ at $4^{\circ} \mathrm{C}$, and the aqueous layer was transferred to new tubes. A 500 $\mu \mathrm{l}$ isopropanol was added to the sample then left at $-20^{\circ} \mathrm{C}$ overnight. The next day, samples were centrifuged again and washed with $1 \mathrm{ml} 70 \%$ ethanol twice before air-drying. Samples were suspended in $10 \mu \mathrm{l}$ of Nano-free water then $2 \mu \mathrm{l}$ of DNAse-buffer [Invitrogen, Inc., CA, USA] and $1 \mu 1$ of rDNAse. Samples were incubated for 30 mins at $37^{\circ} \mathrm{C}$ then $2 \mu \mathrm{l}$ of DNAse inactivation reagent were added. After incubating for 2 mins, samples were centrifuged, and $15 \mu 1$ of total RNA was obtained from each sample determined to be (>100 ng/ $\mu$ l) using NanoDrop ${ }^{\mathrm{TM}} 1000$ [Thermo Fisher Scientific, Inc., MA, USA]. The ratio of absorbance at $260 \mathrm{~nm}$ and $280 \mathrm{~nm}$ were utilized to estimate RNA purity and all RNA isolated samples had a 260/280 ratio of $>1.8$.

\section{6) Primers designing}

The PCR primers were designed using Primer3 and Ensemble databases then confirmed with NCBI nucleotide databases that the primer sequences are 100\% specific for Equus Caballus gene.

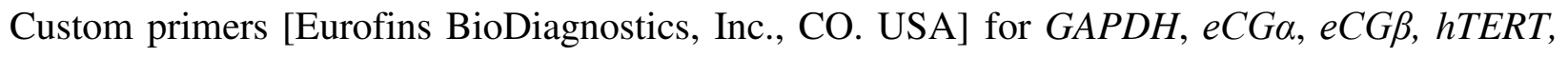
MHCII, and KISSIR were diluted to working stocks before adding to the PCR protocol (table 1). 


\section{7) Reverse transcript $R T-P C R$}

RNA samples were used to produce cDNA using IScript ${ }^{\mathrm{TM}}$ [BioRad, Inc., CA, USA]. The RNA was added based on its concentration to the $4 \mu 15 \mathrm{x}$ Iscript mix, $1 \mu 1$ reverse transcriptase, and Nanofree water added up to $20 \mu$ l. First, the reverse transcription step, the incubation (priming phase) was for 5 mins at $25^{\circ} \mathrm{C}$, then reverse transcription phase for 20 mins at $46^{\circ} \mathrm{C}$, and for $\mathrm{RT}$ inactivation phase for $1 \mathrm{~min}$ at $95^{\circ} \mathrm{C}$. Second, the PCR step, the samples were set up with $2 \mu 1$ cDNA, $22 \mu 1$ Supermix [Invitrogen, Inc., CA, USA], $1 \mu 1$ of that represent a set of primers, each set has forward primer and a reverse one for a specific gene of interest, and all the assay ingredients were added up to $25 \mu 1$. The PCR protocol started with an initial denaturing phase for $1 \mathrm{~min}$ at $95^{\circ} \mathrm{C}$, then 35 cycles of: denaturing phase for $45 \mathrm{~s}$ at $95^{\circ} \mathrm{C}$, annealing phase for $45 \mathrm{~s}$ at $62^{\circ} \mathrm{C}$ (depending on primers), and extending phase for $45 \mathrm{~s}$ at $72^{\circ} \mathrm{C}$. Then a final phase at $72^{\circ} \mathrm{C}$ for 5 mins before holding at $4{ }^{\circ} \mathrm{C}$. Then samples were placed in ethidium bromide $1.5 \%$ agarose gel and electrophoresis separated the negatively charged DNA by size yielding specific amplicon size bands.

\section{8) Media collection and RIA}

Chorionic girdle cell media samples were collected in sterile $1.7 \mathrm{ml}$ Eppendorf tubes from the flasks before changing the media. The samples were collected from each passage and treatment in sterile tubes and stored at $-80^{\circ} \mathrm{C}$ until protein analysis. A single radioimmunoassay (RIA) was performed as previously described (Nett, et al., 1976) (Farquhar et al., 2001) to quantify equine Chorionic Gonadotropin (eCG) using an ovine-derived anti-luteinizing hormone (oLH), which has been demonstrated to cross-react with eCG in commercial qualitative Mare Pregnancy Test (http://csu-cvmbs.colostate.edu/Documents/ria-mare-preg-test.pdf). The intra-assay coefficient of variation of LH $7.9 \%$ and the limit of detection was $188.36 \mathrm{fg} / \mathrm{ml}$ for $\mathrm{LH}$. 


\section{RESULTS}

\section{1) Establishment of chorionic girdle and allantochorion cell lines}

Our first objective was to establish a cell line from chorionic girdle and allantochorion cells derived from day 30 equine conceptuses and infect them with human telomerase reverse transcript hTERT generated using 4 plasmids lentivirus encoding pLV-hTERT-IRES-hygro. The hygromycinresistant cell line was cultured for 10 passages after infection and hygromycin selection. The RTPCR analysis showed that both chorionic girdle and allantochorion cell lines expressed $e C G \alpha$ and $e C G \beta$ genes as specific genetic markers for the equine trophoblast cells, and the $h T E R T$ gene insert was confirmed as well by yielding the predicted bands, (Figure 11,12). To authenticate the cell lines identity, RT-PCR was performed on cell culture passages for presence of $e C G \alpha$ and $e C G \beta$ genetic markers. The amplicon size matched the predicted bands' size as $157 \mathrm{bp}$ for $e C G \alpha$ and 237bp for $e C G \beta$, (Figures 9, 10).

\section{2) Characterization of day 30 embryo's chorionic girdle and allantochorion}

\section{1) Chorionic girdle and allantochorion morphology}

The second objective was to characterize the day 30 embryo invasive trophoblast of chorionic girdle and noninvasive trophoblast of allantochorion. The girdle cells were fast-growing in vitro and showed large, binucleated, well-defined, epithelioid, and decidual-like cells similar to endometrial cups morphology. The allantochorion cells displayed more rapid-growing than the girdle cells in vitro and showed small -relative to girdle-, squamous, mononucleate, epithelioid, and elongated fibroblastic cells (figure 15).

\section{2) Expression of MHC II and KISSR1}

We examined MHC II expression from day 30 chorionic girdle cells and used non-pregnant equine endometrium was as a positive control for MHC II (Maher et al., 1996) expression. The RT-PCR 
analysis showed that MHC II is not expressed in day 30 in chorionic girdle cells (figure 13) congruent with pervious literature. We also investigated KISSRI expression in day 30 equine chorionic girdle using equine hypothalamus as our positive control. Our RT-PCR results demonstrated that $K I S S I R$ is not expressed by day 30 girdle cells as well (figure 13).

\section{3) eCG protein production in vitro from day 30 trophoblast cells}

A third objective of this study was to demonstrate that whether eCG protein is produced in vitro from day 30 girdle and allantochorion cells. The RIA analysis has shown that invasive trophoblast of primary girdle cells produced eCG in the cell culture media as early as day 30 before invading the endometrium and the formation of endometrial cups at day 38. However, the noninvasive trophoblast of allantochrion did not produce eCG in the cell culture media. Moreover, both chorionic girdle and allantochorion cell lines did not produce eCG in vitro after the immortalization steps (figure 17).

\section{DISCUSSION}

Establishing stable cell lines from mammalian cells using cellular oncogenes has many potentials in studying gene expression and cell function. We owe most of our current knowledge of gene expression and regulation of endocrine cells to hormone-producing cell lines feasibility and availability. Thus, we have used a lentivirus encoding $h T E R T$ to construct a stable cell lines originated from equine chorionic girdle and allantochorion cells to which will enable our future studies in investigating its role in equine maintenance of pregnancy. Having a deep understanding of early equine embryonic development and maintenance of pregnancy is important to bridge the gap on knowledge between equids and other species. In fact, primates and equids the only two species known to synthesize a placental gonadotropin. In humans, it is hCG that is the marker for implantation and MRP. However, in horses, it was demonstrated by many that eCG is not the main 
marker of pregnancy and maternal recognition happens earlier between day 11-14 from conception (Short, 1969), (McDowell et al., 1988) before the production of eCG at day 32 (Allan \& Moor, 1972). Our laboratory has multiple ongoing studies investigating the role of miRNAs as potential alternative cell signaling (Klohonatz et al., 2016) and the critical role of embryo content and focal adhesion in MRP (Klohonatz et al., 2019). Our current knowledge about horses MRP is that it is complex and governed by multiple factors compared to other farm animals.

The chorionic girdle cells are the invasive trophoblast cells and the forerunner of endometrial cups that later invade the endometrium by day 38 of conception (Allan \& Moor, 1972). Both girdle cells and endometrial cups share the same characteristics in which they display polygonal epithelial type morphology that supports the notion that the origin of endometrial cups is fetal not maternal (Allan \& Moor, 1972). Both equine chorionic girdle and allantochorion cells are expressing two of glycoprotein hormone family $e C G \alpha$ and $e C G \beta$ subunits in the placenta and this is critical for a deep understanding of maintenance of pregnancy. Thus, establishing a stable cell line of chorionic girdle and allantochorion cells could be one solution to study these research points.

The RIA analysis also showed that eCG protein is not produced in vitro by day $30 \mathrm{CG}$ and AC cell lines, even when the cell line is expressing the mRNA for both eCG subunits. Multiple explanations could be potentially the reason for such occurrence. First, it could be simply because of a low number of RNA copies lead to undetected eCG protein in the media. Second, an example of a prominent cell line that does not produce protein of interest in vitro yet contributed in understanding of pituitary role in regulation of reproduction is alpha T3-1 (aT3-1) cell line. It was considered an immature cell line since it does not produce gonadotropins in vitro but it expresses GnRHR genes mRNA (Barnhart \& Mellon, 1994). The $\alpha \mathrm{T} 3-1$ cell line relied on a gonadotropin specific element binding protein-1(GSEB1), but the DNA-binding domain was abolished during 
establishing the cell line. Third, during establishing the cell line steps and hygromycin selection, we used F-12 media without adding FBS for passage 6 of our experiment because of back-ordering issue. We think it might be one explanation that prevented the production of eCG protein in the media since FBS has growth factors that is critical for cell growth and proliferation. However, RIA analysis showed that eCG presence in the media dropped after passage 4 and the start of infection by lentivirus and cell line steps.

Our CG and AC cell lines demonstrated rapid-growing with a fast doubling time compared to the primary cells doubling time (data not shown). A T75 flask of primary cells took 10 days up to 2 weeks to reach $80 \%$ confluence, but the later passages (P14, P15, and P16) of the cell line reached confluence in one week of culture. This could be another confirmation to the construct of cell line stability and an indication of successful immortalization. Yet, further analysis for telomere length in cell lines could confirm the assumed immortalization. Moreover, our observation showed that the cell line is quite stable compared to primary and culture cells. Approximately around passage 5 (6 weeks in culture) of the cultured cells, the growth-rate got slower and proliferation pace was overtly lower than cell line. Although further analysis is required to have data-driven comparison, this observation can add a valuable insight about the stability of the cell line compared to the primary and cultured cells passages (data not shown). A previous study has shown that when chorionic gridle and allantochorion are cultured together, the cultured cells have a faster growth and produce eCG protein for 180 days after culturing the explants (Allan \& Moor, 1972). However, in order to characterize each cell type of the trophoblast solely, we culture each of them in separate flasks.

Our results have shown that major histocompatibility complex $M H C$ II is not expressed in day 30 chorionic girdle cells. Congruent with what previous studies have shown that MHC II expression 
is suppressed by day 32 in girdle cells (Donaldson et al., 1990) to support the notion ownregulation of specific genes know as major histocompatibility complex primary mechanism to embryo preservation from maternal immunity (Antczak \& Allen, 1984). However, expression at day 30 was not studied before, thus, we examined the expression in day 30 girdle cells.

Our day 30 chorionic girdle cell line is important in studying maintenance of pregnancy from an immunological standpoint. It could be used to study the immunological expression of the major histocompatibility complex MHC I, MHC II, and interleukin IL-22 genes (Mathias et al., 2010) that prevent the mare from rejecting conceptus before the formation of the endometrial cups. Multiple studies have shown that rendering the equine fetal-placental cells almost non-antigenic through down-regulation of the MHC I and MHC II genes by has a critical role in preventing the maternal immune system from rejecting the embryo (Antczak \& Allen, 1984). Thus, the day-30 cell line can be very useful in studying such occurrence in vitro early before the embryo attachment to the endometrium and the formation of endometrial cups.

We also investigated Kisspeptin receptor (KISSIR) expression in day 30 chorionic girdle cells. The current knowledge is that Kisspeptin directly stimulate gonadotropin-releasing hormone GnRH through its receptor KISSIR G-coupled protein (GPR45) in the hypothalamus (Messager et al., 2005). Moreover, human studies showed that KISS1 is highly expressed in the placenta and KISSIR is expressed in cytotrophoblast trophoblast cells and have a critical role regulating trophoblast invasion (Cartwright \& Williams, 2012). Many have studied the effect of injecting Kisspeptin on the release of robust LH and FSH levels in the mice blood (Messager et al., 2005). Given that in horse's LH and eCG- $\beta$ subunit have the similar function, our hypothesis was to search whether Kisspeptin receptors are present in chorionic girdle to regulate eCG- $\beta$ release. 
Unfortunately, our results showed that it is not expressed in equine chorionic girdle and the releasing mechanisms need more investigation.

The RIA results have shown that eCG protein is produced in vitro by the chorionic girdle as early as day 30 of pregnancy. This is a new discovery, since the previous studies hypothesized that eCG would start producing later in the girdle cells life around day 32-35 (Allan \& Moor, 1972). However, $\mathrm{eCG}$ production as early as day 30 is an indication of one of the critical functions of the girdle cells, since only hours after its formation, the girdle cells start producing eCG which is crucial for maintenance of pregnancy. It is noteworthy to mention that because the control samples media included fetal bovine serum (FBS) it yielded cross-reactivity to oLH antibody and give a slightly elevated reading. Further studies on day 28 and day 29 chorionic girdle cells might reveal that $\mathrm{eCG}$ is produced even earlier in vitro which can support the notion of main function of girdle cells from day 28 until day 38 is maintenance of pregnancy.

\section{CONCLUSION}

Our results have demonstrated establishing stable and hygromycin-resistant cell lines from day 30 girdle and allantochorion cells by infecting them lentivirus encoding pLV-hTERT-IRES-hygro is attainable. Also, we showed that equine chorionic gonadotropin eCG is produced in vitro as early as day 30 girdle cells before the formation of endometrial cups. However, our data demonstrated that this cell line doesn't produce eCG protein in the media after the immortalization steps, even when the mRNA for such genes is expressed. Genetic analysis showed that the day 30 girdle and

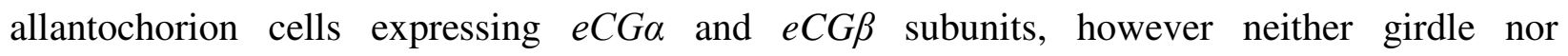
allantochorion cells are expressing MHC II and KISSIR genes. 
CONFLICT OF INTEREST

The author states that there is no conflict of interest that affects the objectivity of the present study. 


\section{FIGURES}

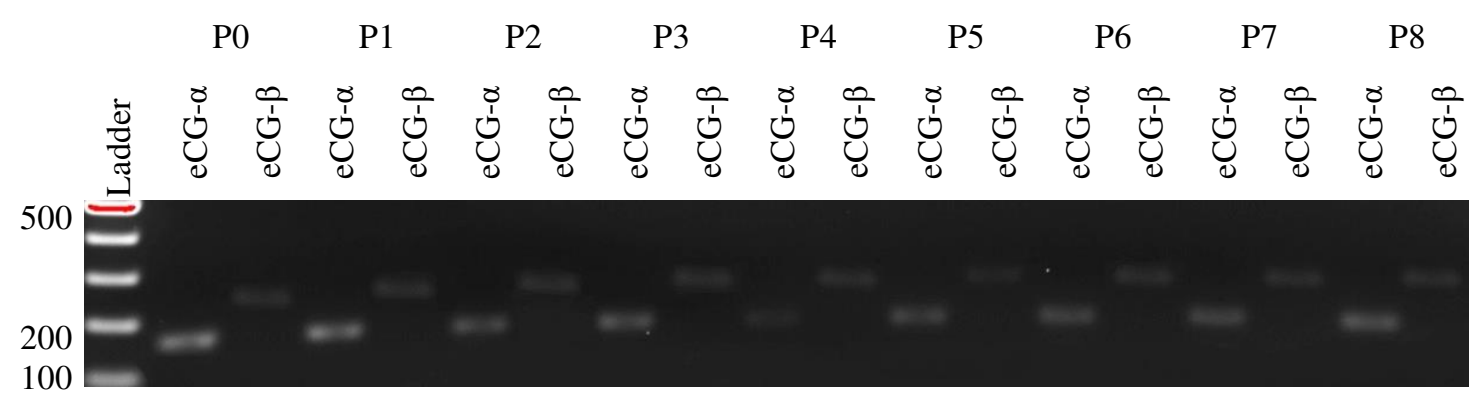

Figure 9: RT-PCR chorionic girdle cells expressing eCG $\alpha$ and $\beta$ subunits in cell culture passages, $\mathrm{P} 0-\mathrm{P} 8$.

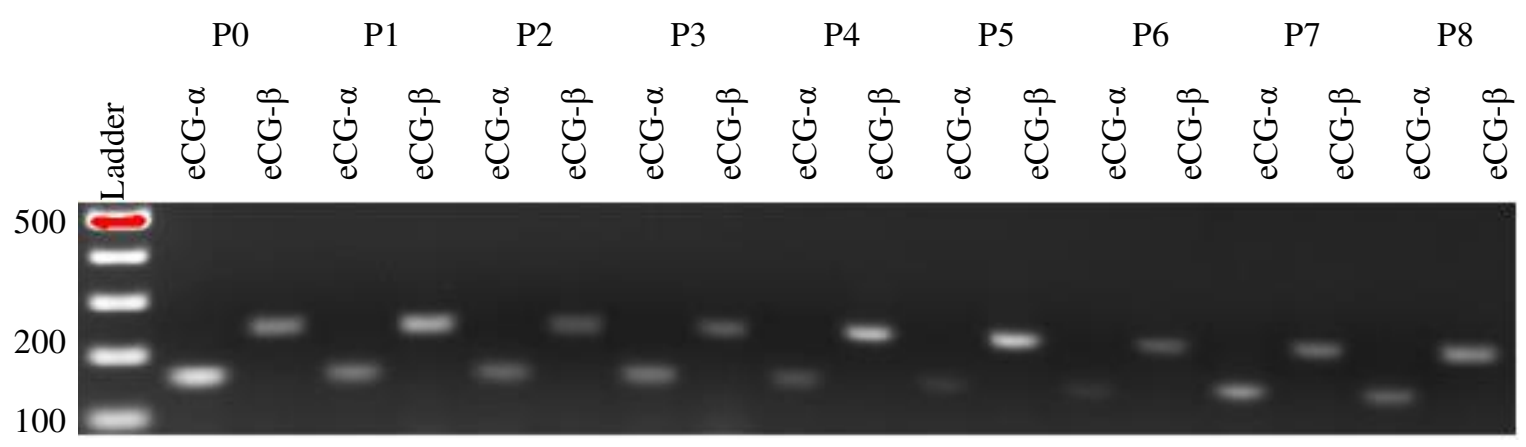

Figure 10: RT-PCR allantochorion cells expressing eCG $\alpha$ and $\beta$ subunits in cell culture passages, $\mathrm{P} 0$ - $\mathrm{P} 8$.

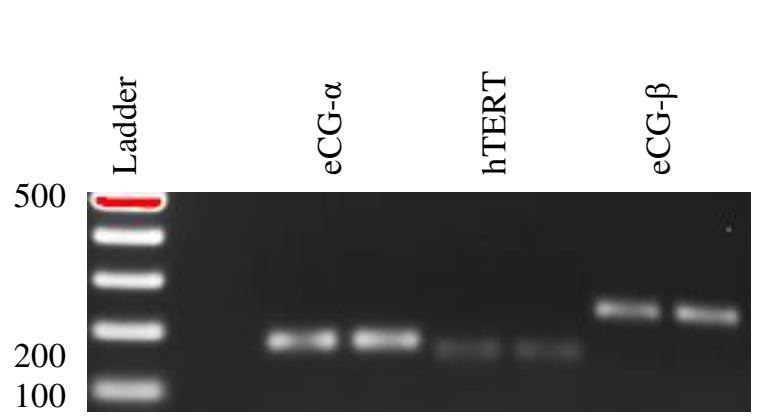

Figure 11: RT-PCR for P8 CG cell line expressing eCG $\alpha, \beta$ subunits, and hTERT genes.

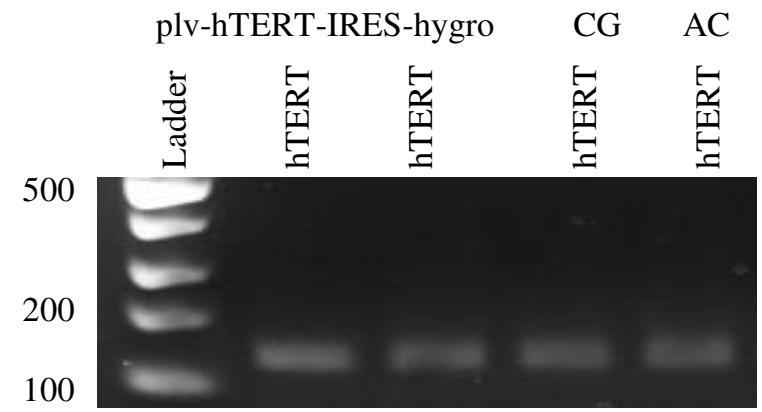

Figure 12: RT-PCR immortalized $C G$ and AC cells expressing hTERT and positive control plv-hTERT-IRES-hygro. 


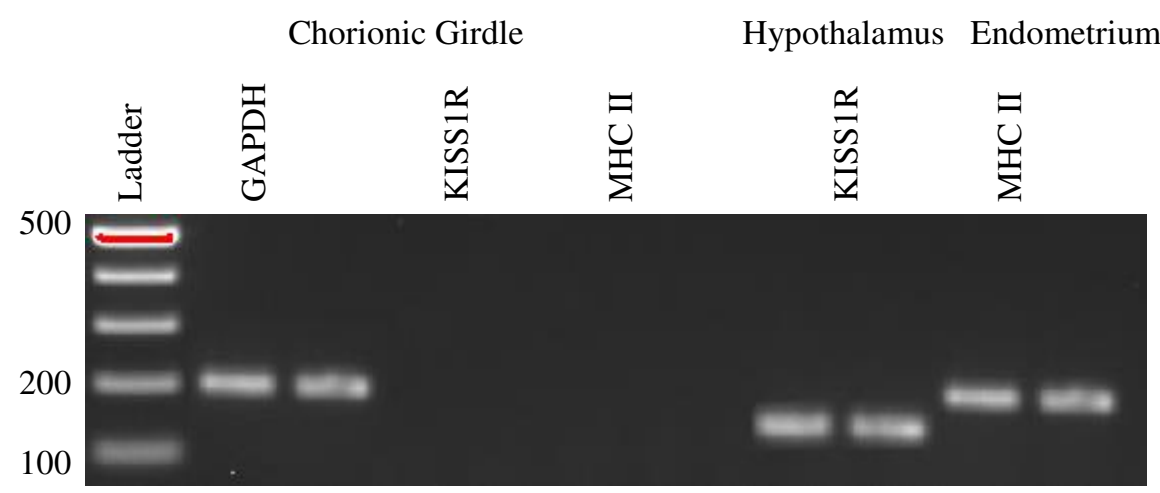

Figure 13: RT-PCR for MHCII and KISS1R. chorionic girdle cells not expressing MHC II or KISS1R genes and hypothalamus and endometrium were used as positive control.

[1]

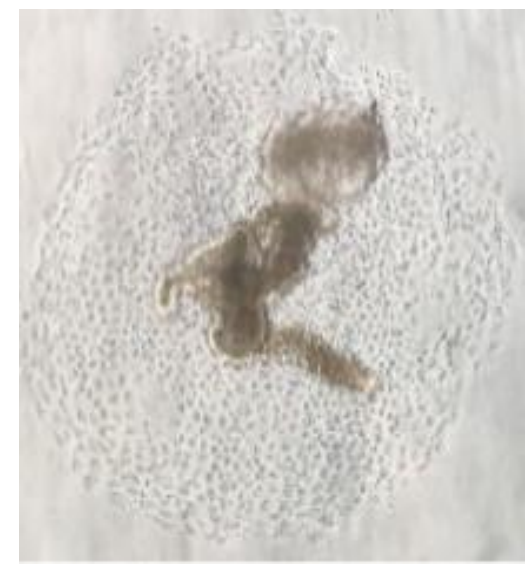

[2]

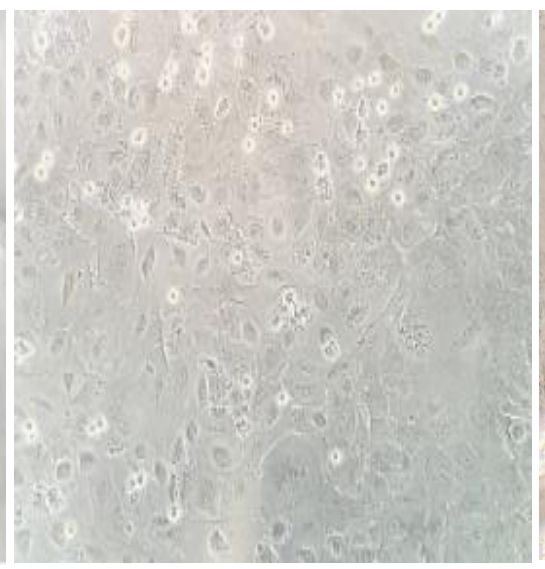

[3]

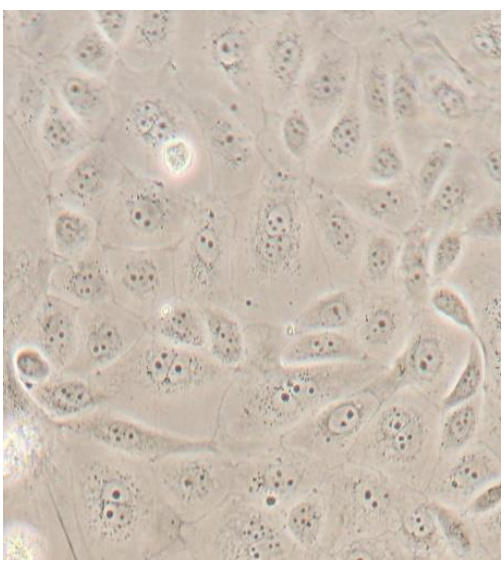

Figure 14: Chorionic girdle cell line in culture; [1] P0 cultured after 12 hours (10x scale). [2] Cells 12 hours after infection (10x scale). [3] Immortalized cells after hygromycin selection (40x scale).

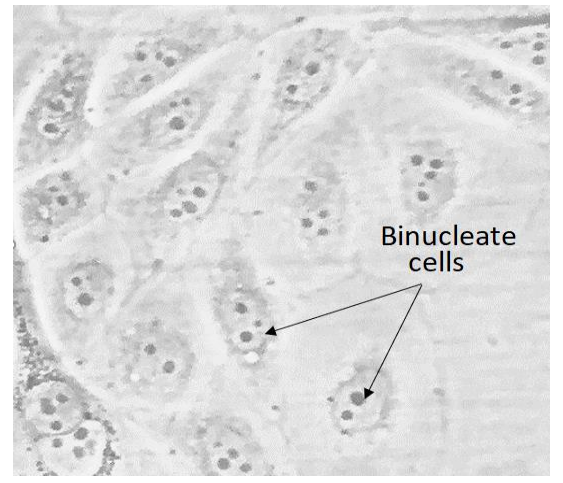

Figure 15: Characterization of day 30 CG cells. CG: large, epithelioid, and binucleate cells (40x scale). 


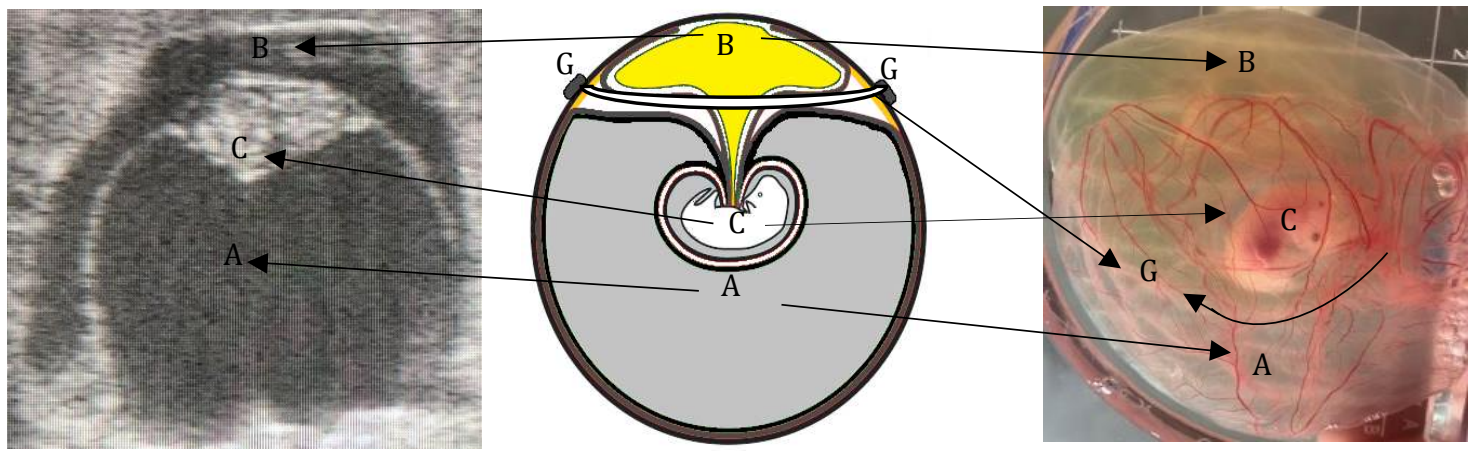

Figure 16: Day 30 equine conceptus; [1] Ultrasonography. [2] Cartoon illustration. [3] conceptus. [A] Allantoic sac, [B] Yolk sac, [C] Embryo, [G] Chronic girdle.

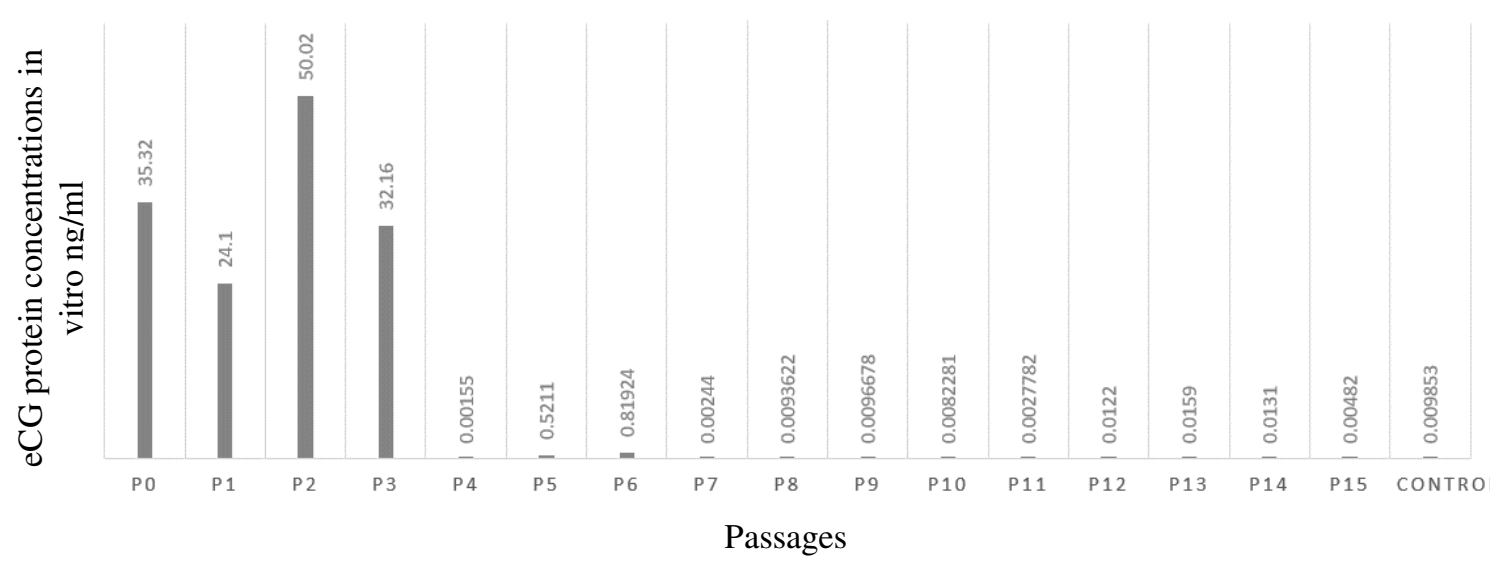

Figure 17: RIA analysis for the eCG protein. Concentration of eCG protein in vitro produced by chorionic girdle cells from passages $0-15$. Using F-12+ FBS as control. P6 media did not include FBS. 


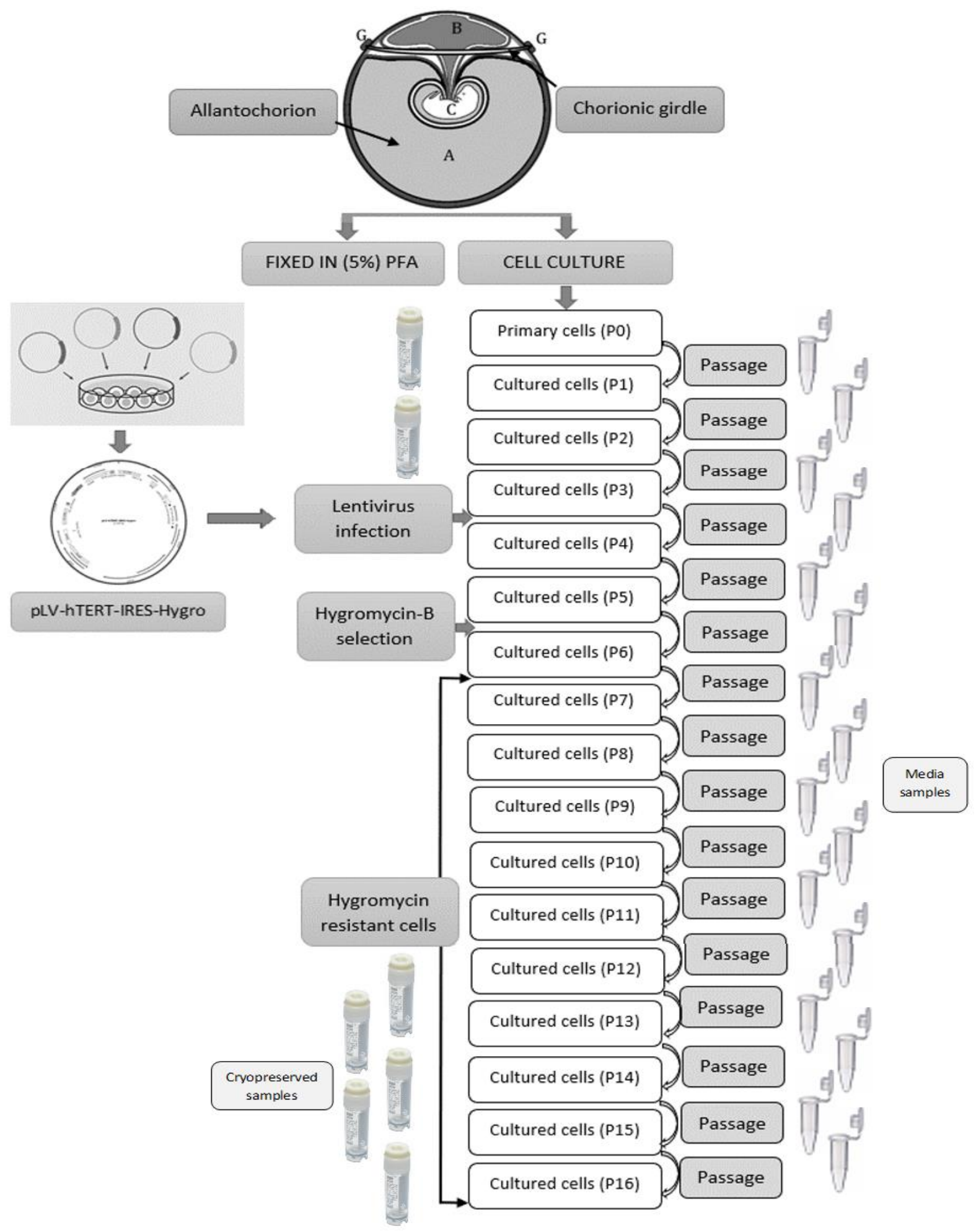

Figure 18: Flow chart for establishing cell line. Immortalization steps and sample collection. 
Table 1: RT-PCR primes sequences. GAPDH, eCG $\alpha$, eCG $\beta$, hTERT, KISS1R, and MHC II primers for their respected genes, and amplicon size.

\begin{tabular}{|c|c|c|c|c|c|}
\hline Gene & Function & $\begin{array}{c}\text { Amplicon } \\
\text { size }\end{array}$ & \multicolumn{2}{|r|}{ Sequence } & $\begin{array}{c}\text { Spanning } \\
\text { intron }\end{array}$ \\
\hline \multirow{2}{*}{ GAPDH } & \multirow{2}{*}{$\begin{array}{l}\text { House- } \\
\text { keeping }\end{array}$} & \multirow{2}{*}{282} & $\mathrm{~F}$ & TTGTCAAGCTCATTTCCTGGTATG & \multirow{2}{*}{ YES } \\
\hline & & & $\mathrm{R}$ & GTTAGGGGGTCAAGTTGGGAC & \\
\hline \multirow{2}{*}{ CGA-201 } & \multirow{2}{*}{ EGC- $\alpha$} & \multirow{2}{*}{157} & $\mathrm{~F}$ & CAGAATGCAAGCTAAGGGAAAACA & \multirow{2}{*}{ NO } \\
\hline & & & $\mathrm{R}$ & CAGCATGTGGATTCTGAGGTGA & \\
\hline \multirow{2}{*}{ hTERT-B } & \multirow{2}{*}{ hTERT } & \multirow{2}{*}{140} & $\mathrm{~F}$ & TCAAGCCTCAGACAGTGGTTC & \multirow{2}{*}{ NO } \\
\hline & & & $\mathrm{R}$ & ACACCGGCCTTATTCCAA & \\
\hline \multirow{2}{*}{ LHß-201 } & \multirow{2}{*}{ EGC- $\beta$} & \multirow{2}{*}{237} & $\mathrm{~F}$ & ATCACCTTCACCACCAGCATCT & \multirow{2}{*}{ YES } \\
\hline & & & $\mathrm{R}$ & GTCTCTGAAAACCCCGCAGTCA & \\
\hline \multirow{2}{*}{ GPR45 } & \multirow{2}{*}{ KISS1R } & \multirow{2}{*}{144} & $\mathrm{~F}$ & TGGTACGTGACGGTGTTCC & \multirow{2}{*}{ NO } \\
\hline & & & $\mathrm{R}$ & TCGAGGACTTGTCCCTCCAC & \\
\hline \multirow{2}{*}{ DQA-201 } & \multirow{2}{*}{ MHC II } & \multirow{2}{*}{216} & $\mathrm{~F}$ & TGACTGCAAGGTGGAGCACT & \multirow{2}{*}{ YES } \\
\hline & & & $\mathrm{R}$ & GGTGCAACTCACAAGCATCC & \\
\hline
\end{tabular}




\section{CHAPTER III: DISCUSSION}

\section{eCG use in farm animals}

The most common use of eCG is the utilization of its FSH activity which induces the estrus in immature animals. The treatment of eCG became the swine industry standard in order to reach puberty in a faster way using a relatively low dose (500 IU). Such dose induces follicle stimulation and when immature gilts received the eCG treatment, it resulted in the expression of estrus in $90 \%$ within 6 days (Bartlett et al., 2009). In ruminants, eCG treatment has been less frequently exploited to stimulate early puberty, however, multiple studies showed that it works successfully in sheep (Sawalha et al., 2011). In dairy cattle, a major reproductive issue is the duration of the postpartum anestrus because of the economic consequences on production. This long interval can be reduced using eCG treatment preceding the first estrous. Shorten anestrus is the goal in many industrial farms and they use multiple ways to achieve this goal. The common approaches are P4 treatment, pituitary stimulation by $\mathrm{GnRH}$, and eCG treatment. More often than not, such treatments are employed together to achieve the best results (Bó et al., 2003).

In the earliest embryo transfer attempts, eCG treatment was administered to induce superovulation in donor animals. Superovulation was achieved using a single eCG injection, but studies have shown that such treatments are inclined to overstimulate the ovary and yielding multiple unovulated follicles (Bevers et al., 1989). Other studies on eCG dose regulation showed that the higher doses (3600 IU/cow) resulted in lower number of transferable embryos, even when they produced a high number of ovulations (Gonzalez et al., 1994). The research demonstrated that most efficacious doses were $2500 \mathrm{IU} / \mathrm{cow}$. Also, the results showed that LH activity of eCG is responsible for reduced embryo quality (Monniaux et al., 1984). Moreover; the eCG treatment has been exploited in fixed-time artificial insemination synchronization protocols in bovine (Sá Filho 
et al., 2010) and ovine (Martemucci \& D'Alessandro, 2011). The eCG treatment dose for fixedtime insemination is around (300 IU/animal) following prostaglandin synchronization (Dias et al., 2009). In summary, eCG induces the estrus in immature animals, increasing pregnancy rate, embryo transfer exploitation, and fixed-time AI synchronization are multiple advantages to eCG treatment.

\section{eCG mechanism to improve reproduction}

The eCG has both FSH and LH activity, and both of these hormones are critical to stimulation and maturation of the mammalian follicle. Many studies demonstrated that eCG treatment improves the chances of having multiple ovulations and elevated circulating P4, however, some studies have shown that $\mathrm{P} 4$ does not correlate positively with increased pregnancy rate (Nogueira et al., 2004). Based on research, the known mechanism is by upregulating luteal function by using low doses of eCG treatment. Thus, mimicking the same effect that takes place in the mare by stimulating and ultimately supporting the secondary corpora lutea during early gestation (Allen, 2001). Recently, a global gene expression study of fixed-time protocol cattle has shown that there are more than 400 genes were in differential abundance in corpora lutea compared to controls. With low doses of eCG treatment at (400 IU) just prior to the end of the protocol showed the aforementioned gene transcriptions (Fatima et al., 2011). This result demonstrates the potential of eCG treatment in fixed-time research in cattle and its future role in bovine reproduction industry.

\section{Girdle cells current and future research}

Equine reproduction is quite challenging, since horses are seasonal breeders, expensive, and hard to handle compared to other farm animals. These are key factors to the future research equine reproduction research output. Adding another prominent factor that hindered the progress of our understanding of maintenance of pregnancy, maternal recognition of pregnancy, and early 
embryonic development is unavailability of cell lines compared to their human counterparts. In humans, a choriocarcinoma cell line that produces hCG gave researchers a great opportunity to deeply study the hCG production and placenta-specific gene expressions (Nilson et al., 1991). Thus, a great solution is constructing stable cell lines that could help greatly in equine research. Since horses breed seasonally and hardly have more than a single conceptus per pregnancy in a given year, the primary cultures of are crucial to any long-lasting research. However, without access to healthy pregnant mares to provide new primary cells for culture every year, the research output will stay stagnant.

Thus, one main objective of our study is to establish a stable equine chorionic and allantochorion cell lines to provide a new model allowing more investigation of gene expression and molecular mechanisms of maintenance of pregnancy and reach a deeper understanding in this research venue. Moreover; this cell line can be used in studying the immunological expression of the major histocompatibility complex (MHC) class I and, class II, and cytokine interleukin IL-22 genes that prevent mare from rejecting conceptus before the formation of the endometrial cups.

\section{The business of eCG}

The eCG protein producing cell line can be used in extraction and purification such protein from the cell culture media in vitro. Thus, the cell line might have an economic potential by producing a valuable product with a high potency commercial eCG products sold based on international units (IU)/batch for both research laboratories and pharmaceutical companies. The future of eCG cell lines is promising. Whether it is in research of equine maintenance of pregnancy, equine embryonic immunogenetic research, eCG role in improving the reproduction of farm animals, or maintaining a profitable, stable, and efficient eCG cell line that reliably produces eCG proteins. 


\section{REFERENCES}

Allen \& Moor. (1972). The origin of the equine endometrial cups. Journal of Reproduction and Fertility, (29), 313-316. https://doi.org/10.1175/JHM-D-14-0178.1

Allen, W. R. (1975). The influence of fetal genotype upon endometrial cup development and PMSG and progestagen production in equids. Journal of Reproduction and Fertility. Supplement, (23), 405-413.

Allen, W. R. (1982). Immunological aspects of the endometrial cup reaction and the effect of xenogeneic pregnancy in horses and donkeys. Journal of Reproduction and Fertility. Supplement, 31, 57.

Allen, W. R. (2001). Luteal deficiency and embryo mortality in the mare. Reproduction in Domestic Animals, 36(3-4), 121-131.

Allen, W. R., Hamilton, D. W., \& Moor, R. M. (1973). The origin of equine endometrial cups. II. Invasion of the endometrium by trophoblast. The Anatomical Record, 177(4), 485-501. https://doi.org/10.1002/ar.1091770403

Amoroso, E. C. (1952). Placentation. Marshall's Physiology of Reproduction, 127-311.

Antczak, D. F., \& Allen, W. R. (1984). Invasive trophoblast in the genus Equus. In Annales de l'Institut Pasteur/Immunologie (Vol. 135, pp. 193-199). Elsevier.

Antczak, D. F., de Mestre, A. M., Wilsher, S., \& Allen, W. R. (2013). The Equine Endometrial Cup Reaction: A Fetomaternal Signal of Significance. Annual Review of Animal Biosciences, 1(1), 419-442. https://doi.org/10.1146/annurev-animal-031412-103703

Antczak, D. F., Miller, J. M., \& Remick, L. H. (1984). Lymphocyte alloantigens of the horse II. Antibodies to ELA antigens produced during equine pregnancy. Journal of Reproductive Immunology, 6(5), 283-297. https://doi.org/10.1016/0165-0378(84)90028-7

Baker, B. M., Gagnon, S. J., Biddison, W. E., \& Wiley, D. C. (2000). Conversion of a T cell antagonist into an agonist by repairing a defect in the TCR/Peptide/MHC interface: Implications for TCR signaling. Immunity, 13(4), 475-484. https://doi.org/10.1016/S10747613(00)00047-9

Balakier, H., \& Pedersen, R. A. (1982). Allocation of cells to inner cell mass and trophectoderm lineages in preimplantation mouse embryos. Developmental Biology, 90(2), 352-362. https://doi.org/10.1016/0012-1606(82)90384-0

Barnhart, K. M., \& Mellon, P. L. (1994). The orphan nuclear receptor, steroidogenic factor-1, regulates the glycoprotein hormone alpha-subunit gene in pituitary gonadotropes. Molecular Endocrinology, 8(7), 878-885. https://doi.org/10.1210/mend.8.7.7527122

Bartlett, A., Pain, S. J., Hughes, P. E., Stott, P., \& van Wettere, W. (2009). The effects of PG600 and boar exposure on oestrus detection and potential litter size following mating at either the induced (pubertal) or second oestrus. Animal Reproduction Science, 114(1-3), 219-227.

Betteridge, K. (1989). Oocyte Fertilisation and Embryo Micromanipulation The structure and function of the equine capsule in relation to embryo manipulation and transfer. Equine Veterinary Journal, 8(Supplement), 92-100. https://doi.org/10.1111/j.20423306.1989.tb04690.x

Betteridge, K. J. (1989). The structure and function of the equine capsule in relation to embryo manipulation and transfer. Equine Veterinary Journal, 21(S8), 92-100.

Betteridge, K. J. (2007). Equine embryology: An inventory of unanswered questions. Theriogenology, 68(SUPPL. 1). https://doi.org/10.1016/j.theriogenology.2007.04.037

Bevers, M. M., Dieleman, S. J., Van Tol, H. T. M., Blankenstein, D. M., \& Van Den Broek, J. 
(1989). Changes in pulsatile secretion patterns of LH, FSH, progesterone, androstenedione and oestradiol in cows after superovulation with PMSG. Reproduction, 87(2), 745-754.

BHAVNANI, B. R., SHORT, R. V, \& SOLOMON, S. (1969). Formation of estrogens by the pregnant mare: I. Metabolism of 7-3H-Dehydroisoandrosterone and 4-14C-

Androstenedione injected into the umbilical vein. Endocrinology, 85(6), 1172-1179.

Billingham, R. E., Brent, L., \& Medawar, P. B. (1953). Activity Acquired Tolerance of Foreign Cells Nature 172: 603-606. Nature, 172, 603-606. Retrieved from http://www.jimmunol.org/content/184/1/5.abstract

Bó, G. A., Baruselli, P. S., \& Martınez, M. F. (2003). Pattern and manipulation of follicular development in Bos indicus cattle. Animal Reproduction Science, 78(3-4), 307-326.

Bousfield, G. R., Liu, W., \& Ward, N. (1987). Structural Studies on Equine Glycoprotein Hormones, 262(18), 8610-8620.

Cartwright, J. E., \& Williams, P. J. (2012). Altered placental expression of kisspeptin and its receptor in pre-eclampsia. Journal of Endocrinology, 214(1), 79-85. https://doi.org/10.1530/JOE-12-0091

Dascanio, J., \& McCue, P. (2014). Equine reproductive procedures. John Wiley \& Sons.

De Mestre, A. M., Hanlon, D., Adams, A. P., Runcan, E., Leadbeater, J. C., Erb, H. N., ... Antczak, D. F. (2011). Functions of ectopically transplanted invasive horse trophoblast. Reproduction, 141(6), 849-856. https://doi.org/10.1530/REP-10-0462

Dias, C. C., Wechsler, F. S., Day, M. L., \& Vasconcelos, J. L. M. (2009). Progesterone concentrations, exogenous equine chorionic gonadotropin, and timing of prostaglandin F2 $\alpha$ treatment affect fertility in postpuberal Nelore heifers. Theriogenology, 72(3), 378-385.

Donaldson, W. L., Zhang, C. H., Oriol, J. G., \& Antczak, D. F. (1990). Invasive equine trophoblast expresses conventional class I Major Histocompatibility Complex antigens. Development, 110, 63-71. Retrieved from http://dev.biologists.org/content/develop/110/1/63.full.pdf

EC, A. (1948). (C) 1948 Nature Publishing Group. https://doi.org/10.1038/162680a0

Enders, A. C., \& Liu, I. K. (1991). Lodgement of the equine blastocyst in the uterus from fixation through endometrial cup formation. Journal of Reproduction and Fertility. Supplement, 44, 427-438.

Farquhar, V. J., McCue, P. M., Nett, T. M., \& Squires, E. L. (2001). Effect of deslorelin acetate on gonadotropin secretion and ovarian follicle development in cycling mares. Journal of the American Veterinary Medical Association, 218(5), 749-752.

Fatima, L. A., Rigoglio, N. N., Bertolin, K., Baruselli, P. S., Gimenes, L. U., Binelli, M., ... Papa, P. C. (2011). Regulation of gene expression in bovine corpus luteum by eCG treatment. In World Congress on Reprod Biol (Vol. 2, p. 153).

Fenstermaker, R. A., Farmerie, T. A., Clay, C. M., Hamernik, D. L., \& Nilson, J. H. (1990). Different Combinations of Regulatory Elements May Account For Expression of the Glycoprotein Hormone $\alpha$-Subunit Gene in Primate and Horse Placenta. Molecular Endocrinology, 4(10). https://doi.org/10.1210/mend-4-10-1480

Freeman, D. A., Weber, J. A., Geary, R. T., \& Woods, G. L. (1991). Time of embryo transport through the mare oviduct. Theriogenology, 36(5), 823-830.

Galli, C., Bevers, M. M., Stout, T. A. E., Lazzari, G., Lagutina, I., Colenbrander, B., \& Tremoleda, J. L. (2004). Effects of In Vitro Production on Horse Embryo Morphology, Cytoskeletal Characteristics, and Blastocyst Capsule Formation. Biology of Reproduction, 69(6), 1895-1906. https://doi.org/10.1095/biolreprod.103.018515 
Gerstenberg, C., Allen, W. R., \& Stewart, F. (2004). Cell proliferation patterns during development of the equine placenta. Reproduction, 117(1), 143-152. https://doi.org/10.1530/jrf.0.1170143

Ginther, O. J. (1983). Mobility of the early equine conceptus. Theriogenology, 19(4), 603-611. https://doi.org/10.1016/0093-691X(83)90180-2

Ginther, O. J. (1998). Equine pregnancy: physical interactions between the uterus and conceptus. American Association of Equine Practitioners Proceedings, 44, 73-104. Retrieved from http://www.ivis.org/proceedings/aaep/1998/Ginther.pdf

GINTHER, O. J. (1985). Dynamic physical interactions between the equine embryo and uterus. Equine Veterinary Journal, 17(S3), 41-47. https://doi.org/10.1111/j.20423306.1985.tb04592.x

Gonzalez, A., Wang, H., Carruthers, T. D., Murphy, B. D., \& Mapletoft, R. J. (1994). Superovulation in the cow with pregnant mare serum gonadotrophin: effects of dose and antipregnant mare serum gonadotrophin serum. The Canadian Veterinary Journal, 35(3), 158.

Griffin, P. G., Carnevale, E. M., \& Ginther, O. J. (1993). Effects of the embryo on uterine morphology and function in mares. Animal Reproduction Science, 31(3-4), 311-329. https://doi.org/10.1016/0378-4320(93)90015-J

Hamernik, L. (1991). Combinations of Regulatory Elements May Explain Why PlacentaSpecific Expression of the Glycoprotein Hormone Gene Occurs Only in Primates I---, 231237. https://doi.org/10.1095/biolreprod44.2.231

Hamilton D.W. , ALLEN, W. R., \& MOOR, R. M. (1973). the Origin of the Equine Endometrial Cups. Reproduction, 29(2), 313-316. https://doi.org/10.1530/jrf.0.0290313

Harold H. Cole. (1943). The source of equine gonadotrophin. https://doi.org/http://dx.doi.org/10.1136/adc.2006.104778

Hayer, A., Shao, L., Chung, M., Joubert, L. M., Yang, H. W., Tsai, F. C., ... Meyer, T. (2016). Engulfed cadherin fingers are polarized junctional structures between collectively migrating endothelial cells. Nature Cell Biology, 18(12), 1311-1323. https://doi.org/10.1038/ncb3438

Hillman, N., Sherman, M. I., \& Graham, C. (1972). The effect of spatial arrangement on cell determination during mouse development. Development, 28(2), 263-278.

Klohonatz, K. M., Cameron, A. D., Hergenreder, J. R., da Silveira, J. C., Belk, A. D., Veeramachaneni, D. N. R., ... Bruemmer, J. E. (2016). Circulating miRNAs as potential alternative cell signaling associated with maternal recognition of pregnancy in the mare. Biology of Reproduction, 95(6), 121-124.

Klohonatz, K., Nulton, L., Bouma, G., Hess, A., \& Bruemmer, J. (2019). The role of embryo contact and focal adhesion molecules during maternal recognition of pregnancy in the mare. Journal of Equine Veterinary Science, 52, 112-113. https://doi.org/10.1016/j.jevs.2017.03.182

Leith, G. S., \& Ginther, O. J. (1984). Characterization of intrauterine mobility of the early equine conceptus. Theriogenology, 22(4), 401-408. Retrieved from http://www.ncbi.nlm.nih.gov/pubmed/16725972

Maher, J. K., Tresnan, D. B., Deacon, S., Hannah, L., \& Antczak, D. F. (1996). Analysis of MHC class I expression in equine trophoblast cells using in situ hybridization. Placenta, 17(5-6), 351-359. https://doi.org/10.1016/S0143-4004(96)90060-0

Martemucci, G., \& D'Alessandro, A. G. (2011). Synchronization of oestrus and ovulation by short time combined FGA, PGF2 $\alpha, \mathrm{GnRH}$, eCG treatments for natural service or AI fixed- 
time. Animal Reproduction Science, 123(1-2), 32-39.

Mathias, J. R., Dodd, M. E., Walters, K. B., Yoo, S. K., Erik, A., \& Huttenlocher, A. (2010). NIH Public Access, 33(11), 1212-1217. https://doi.org/10.1016/j.dci.2009.07.003.Characterization

McDowell, K. J., Sharp, D. C., Fazleabas, A. T., \& Roberts, R. M. (1988). Two-dimensional polyacrylamide gel electrophoresis of proteins synthesized and released by conceptuses and endometria from pony mares. Journal of Reproduction and Fertility, 89(1), 107-115. https://doi.org/10.1530/jrf.0.0890107

McDowell, K. J., Sharp, D. C., Grubaugh, W., Thatcher, W. W., \& Wilcox, C. J. (1988). Restricted conceptus mobility results in failure of pregnancy maintenance in mares. Biology of Reproduction, 39(2), 340-348.

Messager, S., Chatzidaki, E. E., Ma, D., Hendrick, A. G., Zahn, D., Dixon, J., ... Aparicio, S. A. J. R. (2005). Kisspeptin directly stimulates gonadotropin-releasing hormone release via $\mathrm{G}$ protein-coupled receptor 54. Proceedings of the National Academy of Sciences, 102(5), 1761-1766. https://doi.org/10.1073/pnas.0409330102

Min, K. S., Hattori, N., Aikawa, J., Shiota, K., \& Ogawa, T. (1996). Site-directed mutagenesis of recombinant equine chorionic gonadotropin/luteinizing hormone: differential role of oligosaccharides in luteinizing hormone- and follicle-stimulating hormone-like activities. Endocrine Journal, 43(5), 585-593. Retrieved from http://www.ncbi.nlm.nih.gov/pubmed/8980901

Monniaux, D., Mariana, J. C., \& Gibson, W. R. (1984). Action of PMSG on follicular populations in the heifer. Reproduction, 70(1), 243-253.

Murphy, B. D. (2012). Equine chorionic gonadotropin: an enigmatic but essential tool. Animal Reproduction, 9(3), 223-230.

Murphy, B. D., \& Martinuk, S. D. (1991). Equine Chorionic Gonadotropin. Endocrine Reviews, 12(1), 27-44. https://doi.org/10.1210/edrv-12-1-27

Nett, T. M., Pickett, B. W., Seidel Jr, G. E., \& Voss, J. L. (1976). Levels of luteinizing hormone and progesterone during the estrous cycle and early pregnancy in mares. Biology of Reproduction, 14(4), 412-415.

Nogueira, M. F. G., Melo, D. S., Carvalho, L. M., Fuck, E. J., Trinca, L. A., \& Barros, C. M. (2004). Do high progesterone concentrations decrease pregnancy rates in embryo recipients synchronized with PGF2 $\alpha$ and eCG? Theriogenology, 61(7-8), 1283-1290.

Pierce, J. G., \& Parsons, T. F. (1981). Glycoprotein Hormones: Structure and Function. Annual Review of Biochemistry, 50(1), 465-495. https://doi.org/10.1146/annurev.bi.50.070181.002341

Rose, B. V., Cabrera-Sharp, V., Firth, M. J., Barrelet, F. E., Bate, S., Cameron, I. J., ... De Mestre, A. M. (2016). A method for isolating and culturing placental cells from failed early equine pregnancies. Placenta, 38, 107-111. https://doi.org/10.1016/j.placenta.2015.12.014

Rowlands, I. W. (1963). Levels of gonadotrophins in tissues and fluids with emphasis on domestic animals. Gonadotropins: Their Chemical and Biological Properties and Secretory Control, 74-112.

Sá Filho, M. F., Torres-Júnior, J. R. S., Penteado, L., Gimenes, L. U., Ferreira, R. M., Ayres, H., ... Baruselli, P. S. (2010). Equine chorionic gonadotropin improves the efficacy of a progestin-based fixed-time artificial insemination protocol in Nelore (Bos indicus) heifers. Animal Reproduction Science, 118(2-4), 182-187.

Saint-Dizier, M., Chopineau, M., Dupont, J., \& Combarnous, Y. (2004). Expression of the full- 
length and alternatively spliced equine luteinizing hormone/chorionic gonadotropin receptor mRNAs in the primary corpus luteum and fetal gonads during pregnancy. Reproduction, 128(2), 219-228. https://doi.org/10.1530/rep.1.00164

Samuel, C. A., Allen, W. R., \& Steven, D. H. (1974). Studies on the equine placenta. Reproduction, 41(2), 441-445.

Samuel, C. A., Allen, W. R., \& Steven, D. H. (1975). Ultrastructural development of the equine placenta. Journal of Reproduction and Fertility. Supplement, (23), 575-578.

Sawalha, M. N., Kridli, R. T., Jawasreh, K. I., \& Meza-Herrera, C. A. (2011). The use of melatonin and progestagen-eCG to initiate reproductive activity in prepuberal Awassi ewe lambs. Tropical Animal Health and Production, 43(7), 1345-1350.

Schauder, W. (1912). Untersuchungen über die Eihäute und Embryotrophe des Pferdes. Veit. Sherman, G. B., Wolfe, M. W., Farmerie, T. A., Clay, C. M., Threadgill, D. S., Sharp, D. C., \& Nilson, J. H. (1992). A single gene encodes the beta-subunits of equine luteinizing hormone and chorionic gonadotropin. Molecular Endocrinology (Baltimore, Md.), 6(6), 951-959. https://doi.org/10.1210/mend.6.6.1379674

Short, R. V. (1969). Implantation and the maternal recognition of pregnancy. Foetal Autonomy, 2,31 .

Skorupskaite, K., George, J. T., \& Anderson, R. A. (2014). The kisspeptin-GnRH pathway in human reproductive health and disease. Human Reproduction Update, 20(4), 485-500. https://doi.org/10.1093/humupd/dmu009

STEWART, F., Allen, W. R., \& Moor, R. (1976). Pregnant mare serum gonadotrophin: ratio of follicle-stimulating hormone and luteinizing hormone activities measured by radioreceptor assay. Journal of Endocrinology, 71(3), 371-382.

Stout, T. A. E., Meadows, S., \& Allen, W. R. (2005). Stage-specific formation of the equine blastocyst capsule is instrumental to hatching and to embryonic survival in vivo. Animal Reproduction Science, 87(3-4), 269-281.

Talmadge, K., Vamvakopoulos, N. C., \& Fiddes, J. C. (1984a). Evolution of the genes for the $\beta$ subunits of human chorionic gonadotropin and luteinizing hormone. Nature, 307(5946), 3740. https://doi.org/10.1038/307037a0

Talmadge, K., Vamvakopoulos, N. C., \& Fiddes, J. C. (1984b). Evolution of the genes for the $\beta$ subunits of human chorionic gonadotropin and luteinizing hormone. Nature, 307, 37. Retrieved from http://dx.doi.org/10.1038/307037a0

Thway, T. M., Clay, C. M., Maher, J. K., Reed, D. K., McDowell, K. J., Antczak, D. F., ... Wolfe, M. W. (2001). Immortalization of equine trophoblast cell lines of chorionic girdle cell lineage by simian virus-40 large T antigen. Journal of Endocrinology, 171(1), 45-55. https://doi.org/10.1677/joe.0.1710045

Urwin, V. E., \& Allen, W. R. (1982). Pituitary and chorionic gonadotrophic control of ovarian function during early pregnancy in equids. Journal of Reproduction and Fertility. Supplement, 32, 371-381.

Vanderwall, D. K. (1996). Early embryonic development and evaluation of equine embryo viability. Veterinary Clinics of North America: Equine Practice, 12(1), 61-83.

Weber, J. A., Freeman, D. A., Vanderwall, D. K., \& Woods, G. L. (1991). Prostaglandin E2 secretion by oviductal transport-stage equine embryos. Biology of Reproduction, 45(4), 540-543.

WOODS, J., BERGFELT, D. R., \& GINTHER, O. J. (1990). Effects of time of insemination relative to ovulation on pregnancy rate and embryonic-loss rate in mares. Equine Veterinary 
Journal, 22(6), 410-415. https://doi.org/10.1111/j.2042-3306.1990.tb04306.x

Mare Pregnancy Test website (http://csu-cvmbs.colostate.edu/Documents/ria-mare-pregtest.pdf). 